\author{
ARTHUR M. OKUN*
}

Brookings Institution

\title{
Upward Mobility in a High-pressure Economy
}

THE CHOICE OF AN AGGREGATE TARGET of resource utilization remains one of the key issues facing policy makers and macroeconomists. Obviously, fuller utilization of labor and capital brings benefits in the form of extra incomes, output, and jobs; at the same time, it clearly imposes costs by increasing inflationary tendencies. Various economists see these benefits and costs very differently. Henry Wallich once suggested that macroeconomists could be classified into advocates of "high pressure" and "low pressure" operation of the economy. ${ }^{1}$ At the present time, the controversial range for the target unemployment rate extends from 4 to 5 percent. Generally, high-pressure advocates concede that, with existing labor market institutions, unemployment rates below 4 percent would be associated with unacceptable inflation; while most low-pressure advocates agree that unemployment rates above 5 percent are intolerable.

More than a decade ago, I contributed to this dialogue by estimating the bonus in output associated with a high-pressure economy. ${ }^{2}$ I stressed then

* I am indebted to Robert E. Litan and Herbert F. Lowrey, Jr., for their able and extensive assistance in the research, and to George Jaszi and several senior advisers and members of the Brookings Panel on Economic Activity for helpful comments.

1. Henry C. Wallich, “Conservative Economic Policy," Yale Review, Vol. 46 (Autumn 1956), p. 68.

2. Arthur M. Okun, "Potential GNP: Its Measurement and Significance," in American Statistical Association, Proceedings of the Business and Economic Statistics Section (1962); reprinted in Arthur M. Okun, The Political Economy of Prosperity (Brookings Institution, 1970), Appendix, pp. 132-45. 
that unemployment was merely the tip of the iceberg that forms in a cold economy. The difference between unemployment rates of 5 percent and 4 percent extends far beyond the creation of jobs for 1 percent of the labor force. The submerged part of the iceberg includes (a) additional jobs for people who do not actively seek work in a slack labor market but nonetheless take jobs when they become available; (b) a longer workweek reflecting less part-time and more overtime employment; and (c) extra productivitymore output per manhour-from fuller and more efficient use of labor and capital. In light of the findings of other researchers on various aspects of the output-employment relationship, I shall qualify and modify, but basically reaffirm, the three-to-one relationship that I initially estimated between percentage increments in real gross national product (GNP) and percentage-point reductions in the unemployment rate.

That body of research has highlighted several behavioral forces that hold down the addition to unemployment relative to the shortfall of output in a slack economy. Mindful of hiring, training, and recruitment costs, employers hold on to some workers not needed to meet current production schedules. Deterred by search costs, some would-be workers do not hunt for jobs when chances of finding reasonably good ones are poor, and consequently are not counted among the unemployed. Similarly, workers accept cutbacks to part-time employment when full-time jobs are not available.

In addition, I now believe that an important part of the process involves a downgrading of labor in a slack economy-high-quality workers avoiding unemployment by accepting low-quality and less productive jobs. The focus of this paper is on the upgrading of jobs associated with a highpressure economy. Shifts in the composition of output and employment toward sectors and industries of higher productivity boost aggregate productivity as unemployment declines. Thus the movement to full employment draws on a reserve army of the underemployed as well as of the unemployed. In the main empirical study of this paper, I shall report new evidence concerning the upgrading of workers into more productive jobs in a higher-pressure economy.

The demographic groups experiencing the largest proportionate increases in employment in a higher-pressure economy are secondary workers - teenagers and women-who are typically low paid; on the other hand, the industries with the largest relative increases in employment are those that pay high wages and that normally employ a particularly high fraction 
of adult male workers. These results reflect a process of ladder climbing: In part, men formerly in poor jobs move into better ones, making way for women and young people in the less well-paid pursuits; in other cases, a disproportionate share of the additional employment in industries that normally hire men is shifted to women and young people.

On a naive view of the allocation of labor by changes in relative wages, the industries generating the largest increases in employment would be expected to experience the largest increases in wage rates on the road to high utilization. And since these are typically high-wage industries, wage differentials among industries would then be expected to widen. Moreover, since low-skill workers experience especially high unemployment rates, the industries that hire them should be less vulnerable to upward pressure on wages. Yet available evidence on relative wage movements points unmistakably in the opposite direction: Skill differentials and industrial wage differentials tend to narrow-not widen-in a high-pressure economy.

Some recent theoretical analyses emphasize nonprice (nonwage) considerations that determine employment in areas where hiring and training costs are substantial and where employers therefore have strong incentives to promote long-run attachments by their workers. Relying on that nonprice allocative mechanism, I shall sketch a model of the labor market that seems consistent with the behavior of relative unemployment rates, relative wage rates, and shifts in industrial composition of employment associated with a high-pressure economy, hoping to explain why the same forces that make for more jobs also make for better jobs and more output per worker. In conclusion, I shall discuss some implications of the findings and analysis for fiscal, manpower, and wage-price policies.

\section{Output and Productivity Dividends}

When I first estimated that a 1 percentage point decrement in the unemployment rate was associated with a bonus of output approximating 3 percent, I made the basic calculation by a "leap from unemployment to output." I then interpreted that result by reviewing the shreds of evidence available on the various components: the lengthened average workweek, increased participation in the labor force, and extra productivity. Many economists have since studied the parts carefully and built up the estimate of the gap from the separate pieces. 


\section{INCREASES IN LABOR INPUT}

One part of the gap calculation is merely a piece of arithmetic. If participation rates, average hours, and manhour productivity are held constant, the extra jobs associated with reducing the unemployment rate from 5.0 to 4.0 percent would add $1 / 95$ to total labor input and, by assumption, that much-1.05 percent-to real output.

Various researchers have obtained similar results in estimating the lengthened workweek-increased overtime and diminished part-timeassociated with reduced unemployment. Black and Russell, Thurow and Taylor, Perry, and I, have all found that the increment in total manhours due to the lengthening of the workweek is between 0.35 and 0.5 percent for a drop of 1 percentage point in the unemployment rate. ${ }^{3}$ Taylor and Thurow explicitly recognize the use of overtime as a temporary buffer in periods of rapid growth of output; holding the growth of output constant, they estimate that the workweek expands by 0.4 percent for a 1 percentage decrement in the unemployment rate. Perry's estimate standardizes for differences in average hours among various demographic groups; he finds an increase of 0.35 percent in average hours for a decline of 1 point in the official unemployment rate.

I grasped originally at the straw of a calculation of normal labor force by the Bureau of Labor Statistics and guessed that there might be three "hidden unemployed"-people not seeking work actively who would take jobs in a high-utilization economy-for every ten recorded unemployed in excess of a 4 percent unemployment rate. Other studies have generally produced much larger estimates of the number of hidden unemployed. But some of the largest estimates of the participation response are based on statistical techniques that may create an upward bias, as Jacob Mincer demonstrated. ${ }^{4}$ Perry's recent study disaggregates the demographic groups

3. See Stanley W. Black and R. Robert Russell, “An Alternative Estimate of Potential GNP," Review of Economics and Statistics, Vol. 51 (February 1969), p. 72; Lester C. Thurow and L. D. Taylor, "The Interaction Between the Actual and the Potential Rates of Growth," Review of Economics and Statistics, Vol. 48 (November 1966), p. 354; George L. Perry, "Labor Force Structure, Potential Output, and Productivity," Brookings Papers on Economic Activity (3:1971), pp. 541-42 (these volumes are subsequently referred to as $B P E A$, followed by the date).

4. Jacob Mincer, "Labor-Force Participation and Unemployment: A Review of Recent Evidence," in Robert Aaron Gordon and Margaret S. Gordon (eds.), Prosperity and Unemployment (John Wiley, 1966). 
carefully and uses a statistical technique free of bias; on the whole, his estimates tend to be smaller than those of other researchers, partly because he cannot establish a lagged response in annual data. He finds roughly six "hidden unemployed" for every ten recorded unemployed above a 4 percent rate; the increase in participation when the unemployment rate is reduced by 1 percentage point entails an increase in jobs of approximately 0.6 percent. $^{5}$

In light of these other studies, I would now estimate the additional labor input associated with a reduction in unemployment from 5 to 4 percent as follows:

\section{Component}

Jobs for the unemployed

Lengthened workweek

Increased labor force participation

Total addition to labor input

\section{Percent}

1.05

0.40

0.65

2.10

\section{PRODUCTIVITY}

The most perplexing component of the output dividend is the productivity bonus that accompanies a higher-pressure economy. Traditional micro-

5. Perry's estimate of the participation effect is influenced by an important and puzzling data problem. Cyclical spurts and retardations in the growth of employment as reported by firms are substantially more pronounced than those shown in household surveys; for evidence covering 1962-68, see Gloria P. Green, "Comparing Employment Estimates from Household and Payroll Surveys," Monthly Labor Review, Vol. 92 (December 1969), pp. 9-20. Perry relies on the employment estimates from firms, judging them distinctly more reliable than those from households, and he allocates the statistical discrepancy to jobs among women and teenagers, implying a pronounced cyclical pattern of misreporting by households of employment increases.

Black and Russell believed that the statistical divergence reflected cyclical fluctuations in moonlighting. However, since direct estimates of moonlighting do not account for the divergence, Edward Denison has interpreted it as a data discrepancy, and Perry followed that practice. Perry's estimate of increased participation closely matches the sum of the two components that Black and Russell attribute to participation and moonlighting.

The statistical divergence was ignored by some earlier investigators such as Thurow and Taylor, and Edwin Kuh, "Measurement of Potential Output," American Economic Review, Vol. 56 (September 1966), pp. 758-76. By implicitly accepting the household estimates of employment, while basing their productivity estimates on reports from firms, they introduce a downward bias in the estimate of potential. In my 1962 calculation, because I estimated the productivity bonus residually after allowing for increases in labor input as estimated from household surveys, the cyclical pattern of the statistical divergence was incorrectly reflected as extra productivity rather than as extra labor input. 
economic theory implies that firms normally operate under conditions where, holding capital constant, a given percentage increase in labor input would add less than proportionately to output. Yet exhaustive empirical research has generally revealed that manhour productivity is boosted by a rise in employment.

The empirical finding becomes comprehensible once it is recognized that, for a substantial period of time, much of labor input is essentially a fixed cost, reflecting contractual commitments, indivisibilities or complementarity with capital, transaction costs of hiring and firing, and the value of skills that workers have acquired on the job. Thus, in periods of recession or slack, the amount of labor kept on the payroll is greater than the amount technologically required to produce the prevailing depressed level of output. Given the initial presence of such on-the-job underemployment, when demand strengthens, output can be expanded without a commensurate expansion in labor input and a spurt of productivity results. But fixity of labor can explain only a temporary-if perhaps quite lengthy-bonus of productivity from higher output and employment.

The remarkable and intriguing puzzle is that most investigators who have studied the output-employment relationship have not been able to make the productivity bonus from higher utilization disappear, even in the long run. ${ }^{6}$ Robert M. Solow has commented that "the persistence of what appears to be long-run increasing returns with respect to labor alone [is one of the] two big paradoxes, whose resolution would be a major step toward the unification of long-run and short-run theory."7

In light of the work of other researchers, it is clear that both declining unemployment and lower levels of unemployment stimulate productivity. In an upswing of economic activity, both forces operate, but only the level

6. An excellent review of the voluminous literature in this area is presented by Ray C. Fair, The Short-Run Demand for Workers and Hours (Amsterdam: North-Holland, 1969). A recent exception to the typical finding is the aggregate equation in William $D$. Nordhaus, "The Recent Productivity Slowdown," BPEA (3:1972), p. 497.

7. Unpublished presidential address to Econometric Society, delivered December 1965. (Solow's other paradox was the inability to find a significant short-run substitution of capital for labor.) In my judgment, Solow's paradox remains unexplained despite some ingenious efforts. See Frank Brechling and Peter O'Brien, "Short-run Employment Functions in Manufacturing Industries: An International Comparison," Review of Economics and Statistics, Vol. 49 (August 1967), pp. 277-87; Albert A. Hirsch, "Reconciliation of the Short-run Employment Function and the Long-run Production Function" (paper presented at the winter meeting of the Econometric Society, December 1968); Roger Craine, "On the Service Flow from Labour," Review of Economic Studies, Vol. 40 (January 1973), pp. 39-46. 
effect persists. In my initial estimate of the productivity bonus, I did not distinguish between the two sets of forces. The elasticity of output with respect to manhours for the first year of rising utilization can be approximated as 1.5, so that the total increment in output associated with a 2.1 percent addition to manhours exceeds 3 percent. But over a longer horizon - say, three years-the elasticity should be scaled down to about $1 \frac{1}{3}$, pointing to a total increment of output of 2.8 percent. These elasticities are consistent with the productivity bonus found by Black and Russell and with the estimate made by Perry, converted into unweighted manhours, from regressing employment on output. ${ }^{8}$

In short, three to one still looks like a good approximation to the relationship between added output and reduction in the unemployment rate. But that estimate represents rounding downward, as I believed initially, only for the first year, and is probably a slight upward rounding for subsequent years. With potential GNP currently approximating $\$ 1.3$ trillion, the output dividend associated with a choice of a 4 percent rather than a 5 percent unemployment target is between $\$ 35$ billion and $\$ 40$ billion a year, over a horizon of perhaps five years.

Over a long-run horizon of decades and generations, no reasonable estimate is possible. To be sure, on theoretical grounds, one can conclude-as Robert J. Gordon does in this issue-that the productivity bonus must ultimately disappear and even turn negative, thus reducing the size of the output dividend: But even that contention for the undated ultimate long run is subject to skepticism on two grounds. First, the same theoretical reasoning was once interpreted as demonstrating that productivity moved contracyclically in the short run. ${ }^{9}$ Second, it disregards the body of empirical evidence that Solow noted. Fortunately, the horizon relevant to the choices of stabilization policy is not one of decades or generations.

8. Perry, "Labor Force Structure," p. 558. Clearly, the estimates are lower when output is regressed on employment. Kuh reported the same phenomenon in "Measurement of Potential Output." The standard lagged adjustment model of labor demand espoused by Brechling and others cited above would call for employment to be the dependent variable; I am unaware of any analytical model that points toward output as the dependent variable. The statistical pitfalls in this area are discussed by Marc Nerlove, "Notes on the Production and Derived Demand Relations Included in Macro-Econometric Models," International Economic Review, Vol. 8 (June 1967), pp. 223-42.

9. Most notably: “... in general, an increase in employment can only occur to the accompaniment of a decline in the rate of real wages.... This is simply the obverse of the familiar proposition that industry is normally working subject to decreasing returns in the short period ..."-John Maynard Keynes, The General Theory of Employment, Interest and Money (Harcourt, Brace, 1936), p. 17. 


\section{SECTORAL SHIFTS}

One important part of the productivity dividend seems to be associated with shifts of resources toward sectors of higher than average productivity. That portion does not pose the analytical mysteries associated with persistently increasing returns to labor within an industry.

The difference between a high-pressure and a low-pressure economy is not simply a proportionate addition of output and employment across all industries and sectors. The exact distribution of the increments would depend on the source of the added aggregate demand, which might be expansionary monetary policy that would particularly stimulate construction and durable goods; or a wartime military buildup that added especially to the federal sector; or tax cuts and increases in transfer payments that boosted consumer goods industries by an extra margin. Despite these possible differences, history reveals a distinct pattern of resource shifts associated with higher utilization; in particular, the sectoral pattern characteristic of a high-pressure economy is favorable to aggregate productivity.

For example, consider the very broad division of GNP by institutional sectors as product originating in nonfarm business, farms, households, the rest of the world, and government. Empirically, the shortfall of output and employment in a slack economy is found to be concentrated in the nonfarm business sector; agriculture, households, and the tiny rest-of-the-world sector show no cyclical sensitivity; and activity in the government sector is properly regarded as exogenous. ${ }^{10}$ For 1971 , according to published and unpublished estimates of the Department of Commerce, output per manhour in private nonfarm business exceeded output per manhour for the whole GNP by about 20 percent, as shown below:

$\begin{array}{cccc}\text { Sector } & \begin{array}{c}\text { Percent } \\ \text { of total } \\ \text { output }\end{array} & \begin{array}{c}\text { Percent } \\ \text { of total } \\ \text { manhours }\end{array} & \begin{array}{c}\text { Productivity } \\ \text { relative }\end{array} \\ \text { Total GNP } & 100.0 & 100.0 & 1.00 \\ \text { Private nonfarm business } & 85.3 & 71.1 & 1.20 \\ \text { Nonfinancial corporations } & 59.2 & 43.6 & 1.36 \\ \text { Other private nonfarm } & 26.1 & 27.5 & 0.95\end{array}$

10. This view is relevant to fiscal decisions in peacetime, even though government product shows some positive relation to overall economic activity historically as a result of wartime booms. Thus a statistical equation relating real gross government product as a share of real potential GNP to time and an activity variable (the ratio of actual real GNP to potential) reveals that government product accounted for 6.4 percent of the output gap on the average over the period 1954-71. 
Accordingly, even assuming no productivity gain within private nonfarm business, the shift of resources into that sector would boost aggregate productivity. If in such a case the estimated increase of 2.1 percent in total manhours associated with a difference between a 5 percent and a 4 percent unemployment rate is absorbed by private nonfarm business, real GNP would go up 2.5 percent, reflecting the 20 percent productivity bonus from the sectoral shift.

Disaggregation within private nonfarm business raises the possibility of an even greater boost to aggregate productivity from sectoral shifts. As shown above, the higher than average productivity associated with private nonfarm business stems from the especially high productivity of nonfinancial corporations; output per manhour in the remainder of nonfarm business was actually a shade below the economy-wide average. ${ }^{11}$ Nonfinancial corporations also offer high-paying jobs with average hourly compensation about 16 percent higher than the economy-wide average and about 38 percent higher than the average outside that sector. Empirically, the nonfinancial corporate sector accounts for most of the incremental output associated with higher overall utilization. Nonfinancial corporations produce 77.8 percent of the extra output associated with closing the output gap, according to the following equation:

$$
\frac{C}{Y_{p}}=-0.2423+0.00091 t+0.7784 \frac{Y_{a}}{Y_{p}}
$$

$\bar{R}^{2}=0.983$; Durbin-Watson statistic $=0.414$; standard error of estimate $=0.0045$.

Here and in subsequent equations the numbers in parentheses are $t$-statistics.

In the equation, fitted to quarterly data for 1954-71, $C$ is gross product of nonfinancial corporations, $Y_{p}$ is the official series on potential GNP, and $Y_{a}$ is actual GNP, all in 1958 prices; and $t$ is time ranging from 1 in 1954:1 to 73 in $1971: 4 .{ }^{12}$

If productivity within the nonfinancial corporate sector and within the remainder of private nonfarm business remained constant, while 77.8 percent of extra output associated with reduced unemployment was distributed to the first and 22.2 percent to the second, the productivity on the incremental manhours would be 1.24 times the economy-wide average. Given an

11. Since a tiny fraction of the output of nonfinancial corporations is that of farm corporations, viewing that sector as a component of private nonfarm business is imprecise-but only trivially so.

12. The key coefficient of 0.778 was virtually unaffected by the inclusion of lagged terms. It was even higher when adjusted for autocorrelation. 
increment of manhours of 2.1 percent, the resulting gain in output would be 2.6 percent.

Many interesting questions are raised by the strong sensitivity of corporate output to overall utilization, combined with the above average productivity and wage rates of that sector. In a movement from slack to full employment, what fractions of the extra corporate jobs go to the unemployed and to those previously employed in other sectors? How much of the wage premium enjoyed by the average corporate employee goes to new corporate employees? What demographic groups benefit most from the shift? Unfortunately, these questions cannot be answered because the only available data on employment in nonfinancial corporations consist of annual estimates of total manhours in that sector. ${ }^{13}$ At least some answers are possible, however, for industrial sectors, as I shall show below.

\section{The Pattern of Additional Employment}

Who would get the extra jobs in an economy with a 4 percent unemployment rate as contrasted with one of 5 percent? Perry has established that the bulk of the extra jobs would go to women and teenagers-secondary workers-with a disproportionately small gain for adult men. ${ }^{14}$ On the other hand, most of the extra jobs would be created in industries that typically hire a particularly large fraction of adult males; the seeming inconsistency is resolved by a process of upgrading in the labor market.

\section{DEMOGRAPHIC COMPOSITION}

According to Perry's estimates, in 1970, when the official unemployment rate was 4.9 percent, employment was $1,174,000$ below the level that would have been associated with a 4 percent unemployment rate. As a fraction of actual employment, that shortfall or gap in jobs amounted to 1.43 percent. That is consistent with his estimate cited above that, because of the induced drop in labor force participation, a decrement of 1.6 percent in employment accompanies an extra point in the unemployment rate. Perry's disaggregated estimates, displayed in Table 1, reveal a marked disparity in the

13. John A. Gorman, "Nonfinancial Corporations: New Measures of Output and Input," Survey of Current Business, Vol. 52 (March 1972), p. 26.

14. Perry, "Labor Force Structure." 
Table 1. Employment, Actual, Potential, and Gap, by Demographic Group, 1970

Employment in thousands

\begin{tabular}{|c|c|c|c|c|}
\hline $\begin{array}{l}\text { Sex and } \\
\text { age group }\end{array}$ & Actual $^{\mathrm{a}}$ & Potential & $\begin{array}{c}\text { Gap between } \\
\text { potential } \\
\text { and actual }\end{array}$ & $\begin{array}{c}\text { Gap as } \\
\text { percentage } \\
\text { of actual }\end{array}$ \\
\hline Male & & & & \\
\hline $16-19$ & 3,828 & 4,002 & 173 & 4.53 \\
\hline $20-24$ & 6,956 & 7,095 & 139 & 2.00 \\
\hline $25-64$ & 39,319 & 39,616 & 297 & 0.76 \\
\hline $\begin{array}{l}65 \text { and over } \\
\text { Female }\end{array}$ & 2,111 & 2,134 & 23 & 1.08 \\
\hline $16-19$ & 2,766 & 2,912 & 146 & 5.28 \\
\hline $20-24$ & 4,545 & 4,655 & 110 & 2.40 \\
\hline $25-64$ & 21,610 & 21,886 & 276 & 1.28 \\
\hline 65 and over & 1,031 & 1,041 & 10 & 0.96 \\
\hline Total & 82,166 & 83,340 & 1,174 & 1.43 \\
\hline
\end{tabular}

Sources: Actual-estimates by Edward F. Denison and George L. Perry; potential-Perry estimates associated with an official unemployment rate of 4.0 percent. Total and gaps calculated from unrounded data.

a. Including Armed Forces. Estimates do not agree precisely with official labor force data.

percentage employment gaps for the various demographic groups, ranging from less than 1 percent for adult men to about 5 percent for teenagers. Put another way, mature men ( 25 years and over) accounted for half of total employment in 1970 but for only 27 percent of the job gap. Although the rapid growth of secondary workers in the labor force has accentuated this pattern in recent years, it is not a new development. In 1949, for example, when men 25 and over had 61 percent of total employment, they represented 39 percent of the job gap, according to Perry's estimates.

Secondary workers experience larger relative job gaps both because their participation rates are particularly responsive to levels of economic activity and because their unemployment rates decline by a larger amount when the overall unemployment rate falls. For example, Perry estimated that a decline in the overall rate from 5.0 to 4.0 percent implies a reduction of $2 \frac{1}{2}$ to 3 percentage points in the unemployment rate for teenagers, but of only 0.7 or 0.8 percentage points for mature males. ${ }^{15}$ Even though the decline for teenagers is a smaller proportionate drop in their high unemployment rate, it yields a larger proportionate increase in employment.

Compared with mature men, secondary workers typically earn lower

15. George L. Perry, "Unemployment Flows in the U.S. Labor Market," BPEA (2:1972), p. 259. 
wage rates and work fewer hours per week when employed. Because they account for most of the overall job gap, that gap is smaller when weighted by typical wage rates and hours than when viewed as a count of persons. Perry's concept of weighted employment associates with each demographic group the average hours it works and the average wage rate it earns; for 1970, the weighted employment gap was 1.11 percent of total weighted employment in contrast with the unweighted figure of 1.43 percent. If $1970 \mathrm{had}$ been a year of 4 percent unemployment, the average person who would have gained a job would have earned only 78 percent as much as the average worker, assuming that his "new" job involved the average number of hours and average hourly wage experienced by his demographic group.

\section{INDUSTRIAL COMPOSITION}

What kinds of extra jobs are available when the unemployment rate is 4 percent rather than 5 percent? In principle, the distribution of extra jobs could be analyzed in many ways: by institutional sectors (as noted above), or by occupational and skill categories, or by industry. The availability of data-rather than analytical considerations-led me to focus on the pattern of job creation among industries.

To allocate incremental employment by industry, I relied on the employment data by industry published each July in the Survey of Current Business as part of the national income accounts. These data are based on reports from establishments (that is, employers), as are the Denison-Perry estimates. The Commerce series differs from the latter by double-counting people who hold two jobs, and by excluding unpaid family workers; they also differ from Perry's estimates (although not Denison's) by including persons under the age of sixteen. The level of total employment in the Commerce series exceeds Perry's, and the proportionate excess has been rising slowly over time: The number of 14- and 15-year-olds at work has increased as a share of total employment, while unpaid family workers have been declining as a share of the total. Yet taking account of the gentle upward trend, the ratio of Commerce employment to Perry employment has been remarkably stable and shows little sensitivity to overall utilization of the economy. For annual data from 1947 to 1970, the relation takes the following form:

$$
\log \frac{N_{c}}{N_{p}}=0.023+0.00093 t-0.022 \log g
$$

$\bar{R}^{2}=0.959 ;$ Durbin-Watson statistic $=0.917 ;$ standard error of estimate $=0.00136$. 
where $N_{c}$ and $N_{p}$ are total employment measured by Commerce and Perry, respectively; $t$ is time in years $(1947=1)$, and $g$ is the ratio of potential to actual employment as estimated by Perry. Thus, $\log g$ is essentially the Perry employment gap as a ratio to actual employment.

The coefficient on $\log g$ implies that total Commerce employment is depressed by 1.02 percent for each 1 percent employment gap in the Perry data; the difference from unity seems so trivial-as well as being statistically insignificant-that I ignored it. I thus attributed the Perry percentage employment gap to the Commerce data, setting the Commerce employment gap in 1970, for example, at the same 1.43 percent measured by Perry. That estimate in turn implies a measure of total potential Commerce employment. I calculated the ratio of actual Commerce employment for each industry $\left(N_{i}\right)$ to total Commerce potential employment, and then sought to determine how that ratio was affected by variations in the overall employment gap.

The initial statistical exploration revealed one problem of reverse causation. Military employment (and even civilian federal employment) was strongly and negatively related to the employment gap. This result reflected the Korean and Vietnam war booms that fiscal-monetary policies permitted at the same time that federal demand for workers was especially strong. The equations reported the influence of the federal sector on aggregate employment, rather than the way it was influenced by overall employment. Hence, federal employment was taken to be exogenous; total employment for the economy, both actual and potential, was calculated excluding actual employment in the federal sector. As it turned out, this refinement had virtually no influence on the elasticity estimated for any private industry.

For each industry, the log of the ratio of actual industry employment $\left(N_{i}\right)$ to total potential employment-excluding federal- $(P)$ is explained by (1) trend $(t)$ with the year $1947=0$ and $1970=23$; (2) the log of the ratio of total actual employment-excluding federal $-(A)$ to $P$; and (3) the log of the ratio of lagged employment in the industry $\left(N_{i,-1}\right)$ to $P$ :

$$
\log \frac{N_{i}}{P}=a_{0}+a_{1} t+a_{2} \log \frac{A}{P}+a_{3} \log \frac{N_{i,-1}}{P} .
$$

The equations of Table 2 were meant to yield a reasonable set of estimates of $a_{2}$-the elasticity of industry employment with respect to economywide employment. When an employment gap of 1 percent is closed, log $A / P$ rises from -0.01 to zero; the value of $a_{2}$ for any industry describes the 


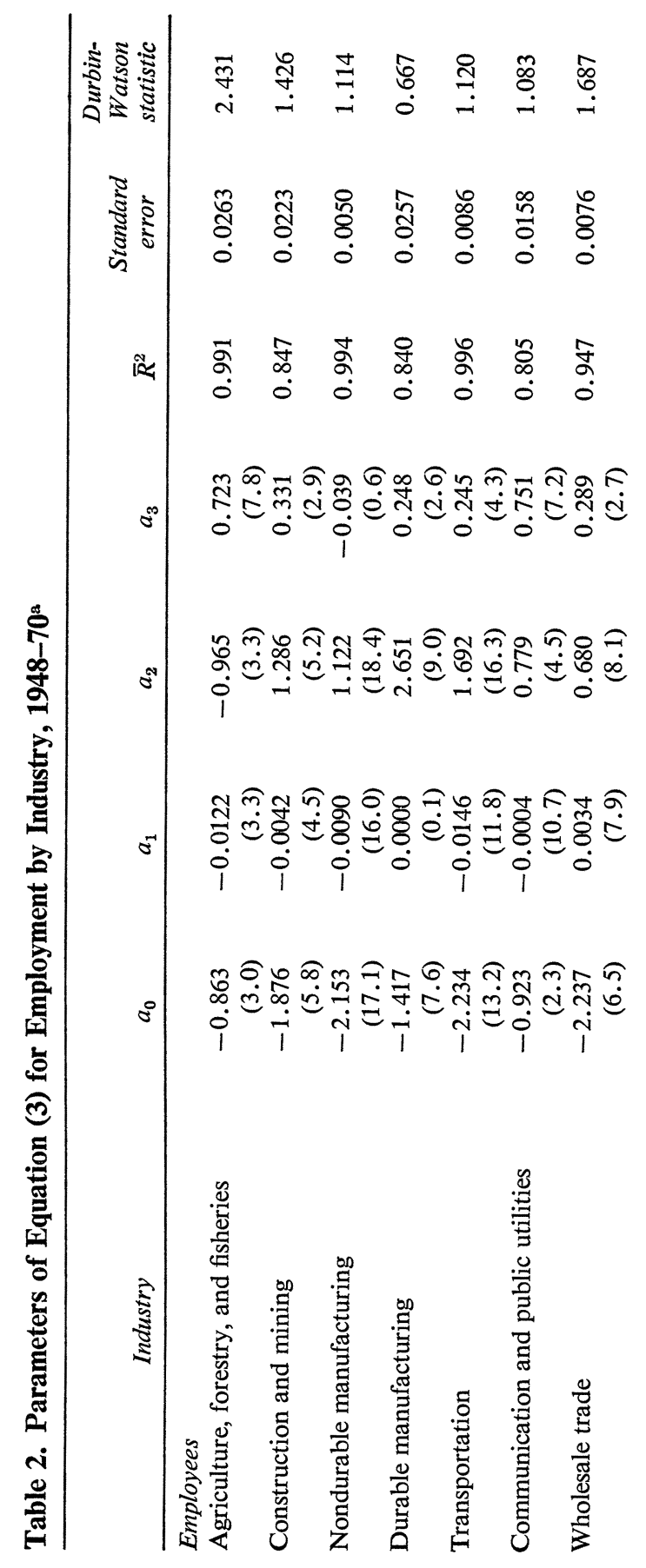




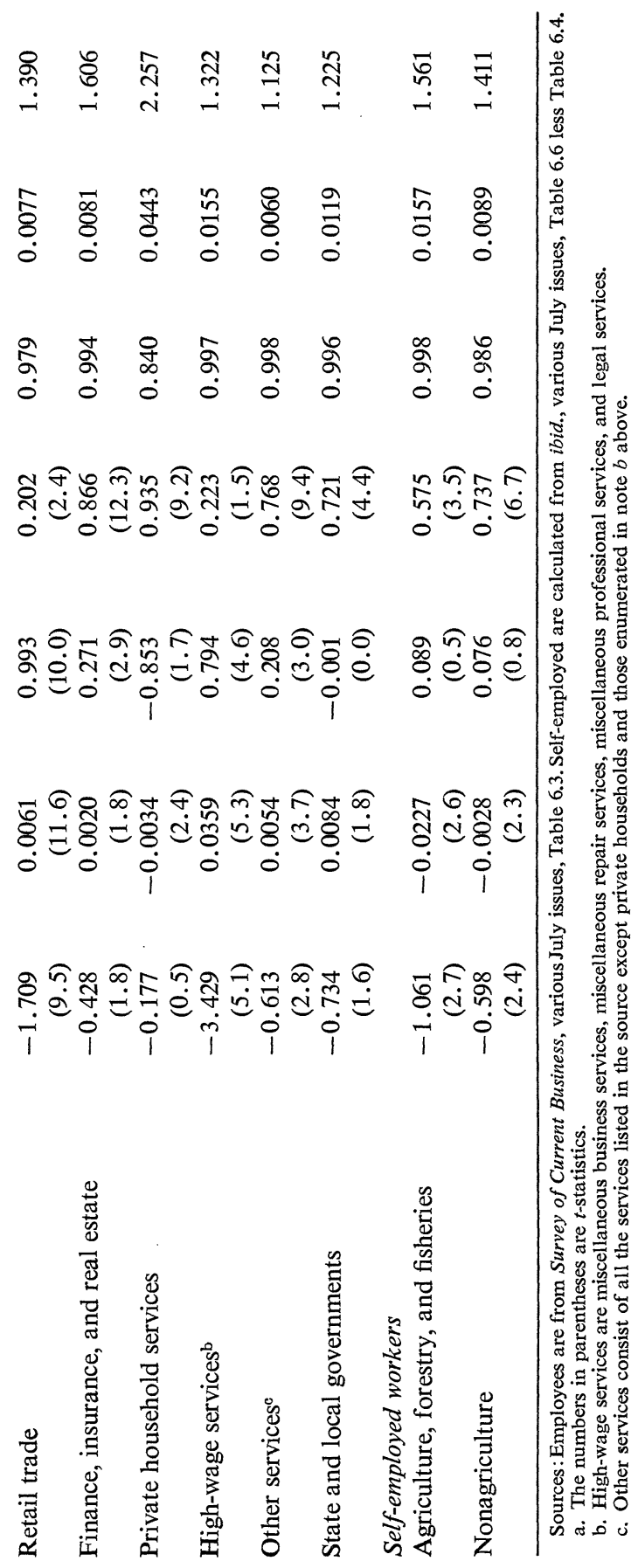


percentage gain in industry employment associated with that 1 percent addition to overall employment. Thus, if an industry's $a_{2}$ exceeds unity, employment in that industry is increased more than proportionately; if $a_{2}$ is zero, industry employment is unaffected; while a negative $a_{2}$ implies that industry employment is contracted under those circumstances.

The other variables in the equations serve merely in a pragmatic way to help refine the estimates of the $a_{2}$ coefficients. Trend is needed to distinguish secular from cyclical forces; lagged employment reduces (although it does not eliminate) problems of serial correlation. Since $P$ is used to normalize both the dependent and independent variables, lagged industry employment is divided by $P$ (rather than lagged $P$ ).

The values of the $a_{2}$ elasticity coefficients shown in Table 2 reveal the big differences among industries in cyclical sensitivity. Durable goods manufacturing wins first prize by a wide margin; its employment is estimated to be 2.65 percent higher when overall employment is 1 percent higher in relation to potential. ${ }^{16}$ Transportation, construction-mining, and nondurable manufacturing also have more than proportionate responses, as shown by $a_{2}$ coefficients exceeding unity. Jobs in retail trade move just about proportionately to total employment. Agricultural and nonagricultural self-employment and employment in state and local governments exhibit remarkable immunity to the gap. Agricultural employees and private household workers showed a decrement of employment at high overall utilization. ${ }^{17}$

In Table 3 the elasticity estimates of Table 2 are used to allocate the employment gap of 1970 by industry. With the federal sector excluded, the percentage gap was 1.54 in 1970; thus the result of multiplying 1.54 times the $a_{2}$ for an industry times actual employment in that industry for 1970, is the estimated employment gap of that industry, shown in the first column of Table 3. The importance of durable goods manufacturing in the job gap stands out. Retail trade and nondurable manufacturing also account for

16. I wondered whether the outstanding elasticity of durable goods employment might reflect, in part, federal arms procurement during the Korean and Vietnam wars. But the errors of the durable goods equation for the war years were not at all unusual, suggesting that the production of durables for the federal government substituted at least in large measure for durable items that would have been acquired by private investors and consumers in a peacetime economy with equally high utilization rates.

17. Because I set 1 million workers as the minimum size of industry to get its own equation, mining was added to construction. I separated and grouped the "high-wage" services-miscellaneous business, miscellaneous repair, miscellaneous professional, and legal-expecting them to show greater cyclical responsiveness than the other services, as they did. That was the only experiment performed to disaggregate industries more finely. 
substantial parts of the job gap; although their elasticities are not particularly high, they are very large industries. But so are other services and state and local governments, and yet they account for only a trivial part of the job gap. The tendency of poor overall job opportunities to keep workers down on the farm and in domestic service is reflected in negative job gaps for those sectors.

The nature of the equations does not ensure that the total employment gap will be allocated among the industries. In fact, the estimates allocate a little more than 1.0 million jobs to the various industries, rather than the 1.2 million total in the Commerce employment gap. ${ }^{18}$

Key characteristics. In comparison with the demographic composition of the employment gap discussed above, the industrial composition reveals two remarkable divergences:

(1) In the industries with high elasticities and large job gaps, men 25 and over typically account for an especially large share of employment. The last column of the table reveals that relationship as well as a few exceptions (agricultural self-employment on the one hand; retail trade on the other). If each industry filled its job gap in 1970 without altering the demographic composition of its work force, men 25 and over would have obtained 61 percent of the extra jobs, in sharp contrast with the 27 percent demographic estimate of the job gap for that group. Teenagers, who also had 27 percent of the demographic job gap, would have obtained only 6 percent of the extra jobs if the demographic composition within industries had been unchanged.

(2) The industries with relatively large employment gaps typically offer high-paying jobs. Average compensation for employees in the employment gap weighted by the index of annual earnings by industry (the fifth column of the table) was 16 percent above the economy-wide average for all workers, a striking contrast to the 22 percent shortfall below economy-wide average earnings yielded by the demographic estimates. Again exceptions can be found-such as finance, insurance, and real estate, and retail tradebut the average relationship is strong.

The industrial composition of the job gap is also tilted toward those in-

18. When treated like any other industry, military employment had a value of $a_{2}$ of 3.6, showing greater cyclical sensitivity than even durable goods manufacturing! Even with the gap redefined to exclude federal workers, part of the difference between the sum of the industry totals and the overall employment gap reflects the excluded military component of more than 150,000 workers in the job gap of 1970 . 


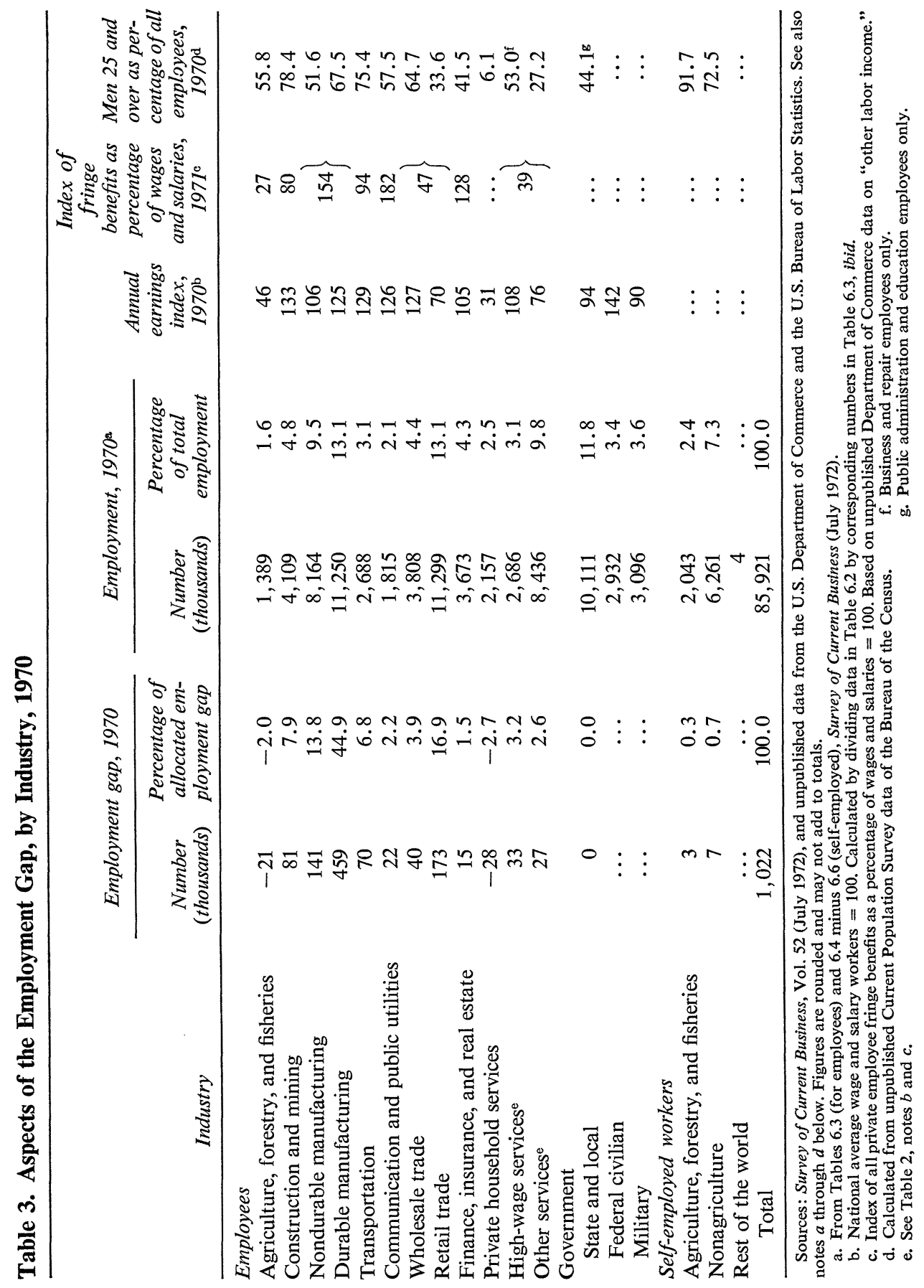


Table 4. Employment Gap, 1970, and Productivity Relatives, 1971, by Industry

\begin{tabular}{lcc}
\hline \multicolumn{1}{c}{ Industry } & $\begin{array}{c}\text { Percentage of } \\
\text { allocated employ- } \\
\text { ment gap, 1970 }\end{array}$ & $\begin{array}{c}\text { Manhour produc- } \\
\text { tivity relatvies, } \\
1971\end{array}$ \\
\hline Agriculture, forestry, and fisheries & -1.7 & 0.66 \\
Construction and mining & 8.0 & $1.04^{\mathrm{a}}$ \\
Nondurable manufacturing & 13.8 & 1.25 \\
Durable manufacturing & 44.9 & 1.23 \\
Transportation & 6.8 & 1.30 \\
Communication and public utilities & 2.2 & $2.74^{\mathrm{a}}$ \\
Wholesale and retail trade & 21.1 & 0.93 \\
Finance, insurance, and real estate & 1.5 & 3.06 \\
Services & 3.4 & 0.56 \\
Government & 0.0 & 0.51 \\
Total & 100.0 & $\ldots$ \\
\hline
\end{tabular}

Sources: Employment gap, Table 3, with self-employed allocated among the industry groups; productivity relatives, William D. Nordhaus, "The Recent Productivity Slowdown," BPEA (321972), p. 522.

a. Weighted averages of the two industries using 1971 employment data from Table 6.3, Survey of Current Business (July 1972).

b. Includes private households, high-wage services, and other services.

dustries that seem to have stronger attachments between employers and employees. One crude measure of employers' efforts to retain workers over the long run is the volume of fringe benefits (pensions, insurance, and so on). When the job gap by industries is weighted by an index of the proportion of private fringe benefits to wages and salaries among industries (the next to last column of the table), the resulting index of fringes for the jobs in the employment gap is 22 percent above the national average for all private employment.

Finally, the job gap is concentrated in industries with above average output per manhour. In Table 4, Nordhaus' cyclically corrected estimates of productivity relatives among industries for 1971 are shown, after some adjustment to match the industry disaggregation used in Table $2 .{ }^{19} \mathrm{Al}-$ though they refer to manhours of all labor (employees and the self-employed), they should give a rough indication of productivity associated with the employment gap for 1970 identified in Table 3. While there are clear exceptions, most of the added employment would go into industries of above average productivity. The average output per manhour associated with the 1970 employment gap is 21 percent above the economy-wide average.

19. Nordhaus, "Recent Productivity Slowdown," p. 522. 
Obviously, the wage rates, fringes, and productivity of incremental workers in an industry should lie below the average of existing workers in that industry. Yet the available evidence on the earnings of various demographic groups in various industries and occupations suggests that positions that pay high wages pay higher than average wages to each demographic group of workers. ${ }^{20}$ Clearly, the earnings (and presumably the productivity) of any worker depend both on his demographic and personal characteristics and on the kind of job he gets. The truth must lie somewhere between the low weights on incremental employment yielded by the demographic characteristics and the high weights associated with the industrial composition. Demographic weighting of incremental employment implies that industrial shifts have no effect-that extra employees earn and produce at average levels associated with their demographic reference groups, regardless of where they are employed. On the other hand, industrial weights imply that pay and productivity are unaffected by the youth and inexperience of the incremental workers. Neither of these extremes is tenable.

Questions about the longer run. The allocation of the employment gap for 1970 in Table 3 is essentially a short-run estimate. It reflects the impact of the current level of the employment gap on the industrial composition of employment. However, one statistical test demonstrated conclusively that the $a_{2}$ coefficients reflect the level of the employment gap and not the change in the gap. The lagged value of $A / P$ was used as an additional explanatory variable in equation (3), but the coefficients on that term were uniformly trivial (even when lagged industry employment was omitted). If any significant part of the employment patterns I have attributed to high utilization were merely the result of rising utilization, then that lagged gap variable should have revealed that influence.

Nonetheless, the immediate impact cannot be sustained indefinitely without some alteration. If the economy shifted permanently from a 5 per-

20. For evidence that occupational earnings relatives are similar among male age groups, see U.S. Bureau of the Census, Current Population Reports, Series P-60, No. 58, "Year-Round Workers with Low Earnings in 1966" (1969), p. 17. Age-sex occupational earnings relatives were strikingly similar in 1960, according to Bureau of the Census, U.S. Census of Population, 1960: Occupational Characteristics, Final Report PC(2)-7A (1963).

Unfortunately, the data by industry are less complete. Earnings by industry are classified by sex in the annual issue of Current Population Reports (Series P-60) on income of families and persons, and these suggest that industry earnings relatives are generally comparable between sexes. But the same comparisons cannot be made across age groups from any body of data I know. 
cent to a 4 percent unemployment rate, stocks of durable goods would ultimately be adjusted upward in balance with the higher levels of income and output, and the especially high elasticity of durable goods employment could not be maintained forever. Some crude calculations suggest to me that the catch-up in stocks could sustain a proportion of employees in durable goods manufacturing of 13.5 rather than 13.1 percent (as implied by Table 3), for roughly six years. Presumably, the share of durable goods would then drop off, but not necessarily to its original level. It is not obvious that, even ultimately, the capital-labor ratio of the high-pressure world would necessarily be precisely that of the low-pressure world. Relative supplies of labor among industries would be different; learning by doing could change productivity relatives; and so forth. In particular, the high-pressure world would mean permanently higher recruitment costs for employers, higher vacancy rates, and higher quit rates. These forces would maintain indefinitely a longer workweek involving more overtime and less involuntary part-time work, and might also keep pushing employers to substitute capital for labor. In any case, the skills accumulated during years of employment in durable goods manufacturing may make workers much more adaptable for good jobs elsewhere.

The gradual growth of stocks of assets in the high-pressure world would tend to expand employment in finance, insurance, and real estate gradually over a longer-run horizon, far beyond the rather small short-run increment reflected in an $a_{2}$ of 0.271 . This is the exceptional sector that has aboveaverage earnings, fringes, and productivity yet displays a very low $a_{2}$. Finally, in the case of domestic workers and farm workers, a high-pressure economy would mean a permanently lower supply of labor seeking refuge from unemployment in these low-grade jobs; the reduction in supply would alter relative wages and relative prices and induce permanent and perhaps even cumulative contraction.

In principle, the lagged industry employment variable in equation (3) permits an assessment of these longer-run influences. The $a_{3}$ coefficient can be viewed as a secondary effect of the employment gap next year through its influence on industry employment this year. However, the lagged employment term also reflects many other forces that persist over time and make the composition of employment less volatile. If one takes this lagged adjustment process seriously as an estimate of the continuing effects of the gap, some of the results seem plausible and some do not. As expected, the response of finance, insurance, and real estate to maintained high pressure 
builds up very gradually. The exodus of household and farm workers is implied to move at only a snail's pace-perhaps implausibly slowly. Increases in jobs in durable goods manufacturing after several years are estimated to be even larger than those in the initial year or two-contrary to one's strong a priori convictions. I myself would not view the $a_{3}$ coefficients as serious estimates of a longer-run adjustment. Indeed, I would have little hope that the essence of such a process could be distilled from the data of a fluctuating economy. But for anyone who might wish to make such an interpretation, I have shown the allocation of the incremental employment that is implied by equation (3), assuming that 4 percent unemployment is maintained for one year, two years, five years, and indefinitely in an economy like the United States in 1970. (See Table 5.)

Regardless of how one interprets these data, they suggest that the resource patterns characteristic of differing utilization rates last long enough to be relevant to the stabilization choices facing the American economy. The upgrading benefits may not be maintained indefinitely in the form of the industrial shifts estimated for the short run; but there is no reason to believe that these benefits, and the accompanying boost to overall productivity, are simply ephemeral.

\section{DEMOGRAPHIC SHIFTS WITHIN INDUSTRIES}

According to the findings above, the demographic gap contains too many young people and too few mature men to fill the slots in the industrial gap with unchanged demographic proportions in each industry. Thus the demographic shares of industry employment must be related to the level of the utilization in the economy, at least for some industries.

I was able to investigate cyclical shifts in the demographic composition of employment within industries, through the cooperation of John E. Bregger of the Bureau of Labor Statistics. He supplied unpublished annual data for 1961-72 that cross-classify the employment reported in monthly household surveys by industry and by age-sex group. These data thus estimate the number of teenagers, men, and women employed in construction, trade, and the other industries. I used six demographic categories, separating males and females into three age groups: 16-19, 20-24, and 25 and over.

In principle, these data provided an employment matrix of $N_{i d}$ entries where $i$ represents an industry and $d$ a demographic group. Each row total (summing over the six demographic groups for a given industry) should 


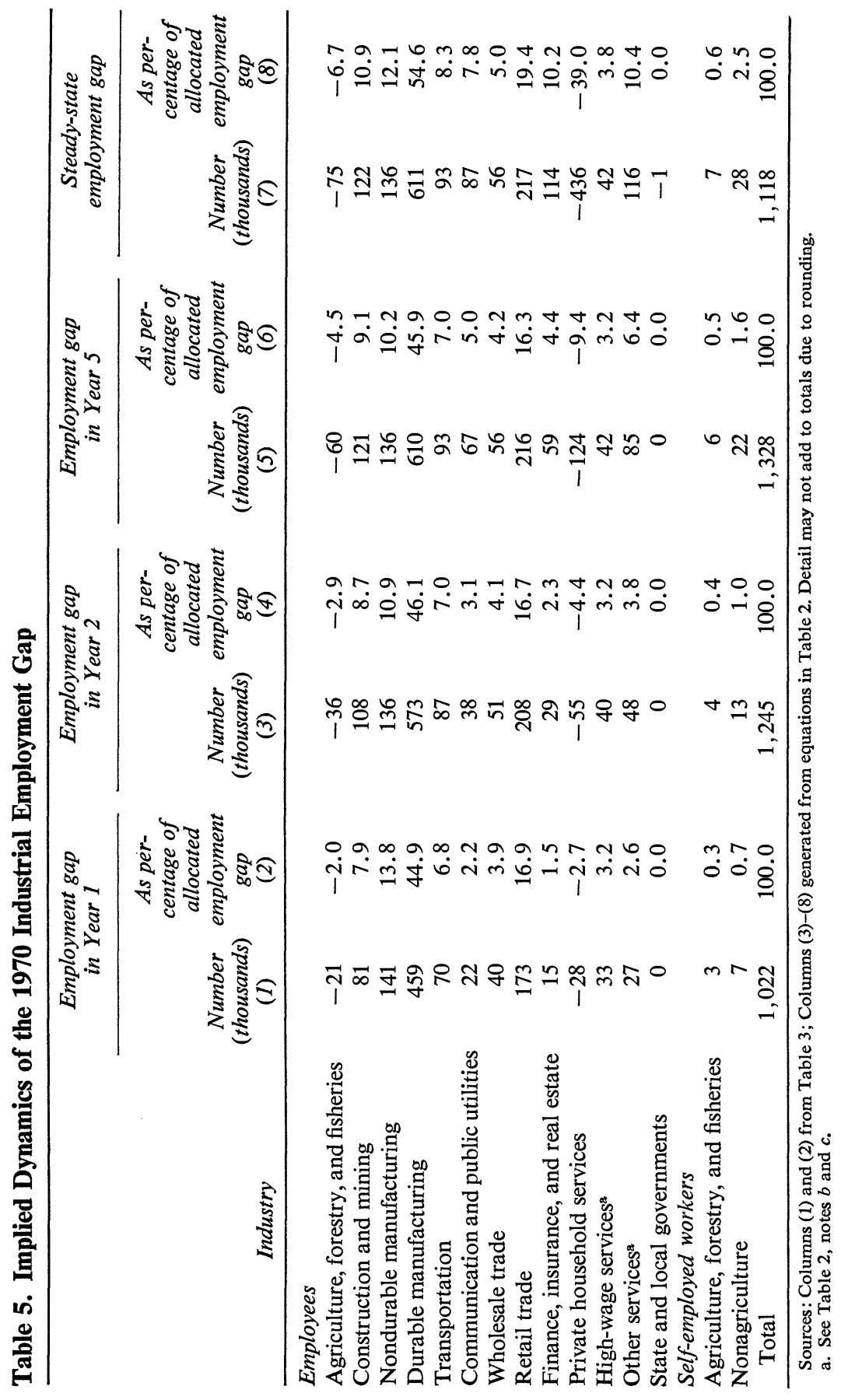


yield total employment for an industry; each column total (summing over industries for a given demographic group) should yield total employment for a demographic group. In fact, estimates of industry employment from the household surveys do not accord precisely with the more reliable reports from establishments. Nor do the employment totals for each demographic group uniformly agree with those estimated by Perry, since he adjusted employment to conform to the establishment-based total.

I assumed that the data from household surveys supply accurate estimates of the composition of workers in any industry among the six demographic groups, without accepting the total employment estimates either for demographic groups or industries. Thus I focused on the values of $N_{i d} / N_{i}$ yielded by the data, in effect assuming that any error in $N_{i}$ was spread proportionately among the six demographic groups.

I fitted to the annual observations for 1961-72 the following equation:

$$
\frac{N_{i d}}{N_{i}}=b_{0}+b_{1} t+b_{2} g
$$

where the dependent variable is the share of group $d$ in the employment of industry $i$ expressed as a percentage; $t$ is time measured in years from $1961=1$; and $g$ is the Perry employment gap expressed as a percentage of total employment (thus, for $1970, g=+1.43$ ). For each industry, six equations were fitted, corresponding to the six demographic groups. The equations were specified so that the sum of the $b_{2}$ coefficients over the six groups in each industry would be zero, obeying the identity that total industry employment is the sum of its employment over the six demographic groups. The trend term is meant to distinguish secular from cyclical forces. Employment includes the self-employed, since separate data on employees were not available for part of the period. Moreover, since the data did not distinguish between public and private employment in education, the industry categories had to be altered, as detailed in Table 6 .

The coefficient $b_{2}$ indicates whether the share of a demographic group in the employment of a given industry is responsive to overall labor market pressure. If $b_{2}$ equals zero, as it does for males 20-24 in transportation (Table 6), the share of transportation jobs that go to male youths is found to be independent of the employment gap; the number of jobs they have in that industry is changed in proportion to the industry total. A positive value of $b_{2}$, such as the 0.68 estimate for men 25 and over in durable goods manufacturing, implies that the share of that group in the industry's em- 
Table 6. Coefficients $\left(b_{2}\right)$ on Percentage Employment Gap for Equation (4), by Industry, Sex, and Age Group ${ }^{\mathrm{a}}$

\begin{tabular}{|c|c|c|c|c|c|c|}
\hline \multirow[b]{2}{*}{ Industry } & \multicolumn{3}{|c|}{ Males } & \multicolumn{3}{|c|}{ Females } \\
\hline & $16-19$ & $20-24$ & 25 and over & $16-19$ & $20-24$ & 25 and over \\
\hline Private household services & $\begin{array}{l}0.144 \\
(3.78)\end{array}$ & $\begin{array}{l}0.063 \\
(2.59)\end{array}$ & $\begin{array}{l}0.042 \\
(0.87)\end{array}$ & $\begin{array}{r}-0.056 \\
(0.45)\end{array}$ & $\begin{array}{l}0.022 \\
(0.32)\end{array}$ & $\begin{array}{r}-0.214 \\
(1.66)\end{array}$ \\
\hline $\begin{array}{l}\text { Agriculture, forestry, and } \\
\text { fisheries }\end{array}$ & $\begin{array}{l}0.125 \\
(3.29)\end{array}$ & $\begin{array}{l}0.308 \\
(4.32)\end{array}$ & $\begin{array}{r}-0.380 \\
(3.02)\end{array}$ & $\begin{array}{l}0.072 \\
(2.54)\end{array}$ & $\begin{array}{l}0.066 \\
(3.51)\end{array}$ & $\begin{aligned}-0.191 \\
(2.64)\end{aligned}$ \\
\hline Construction and mining & $\begin{array}{r}-0.021 \\
(0.45)\end{array}$ & $\begin{array}{l}0.365 \\
(3.64)\end{array}$ & $\begin{array}{r}-0.376 \\
(2.60)\end{array}$ & $\begin{array}{r}-0.013 \\
(2.51)\end{array}$ & $\begin{array}{r}-0.006 \\
(0.45)\end{array}$ & $\begin{array}{l}0.051 \\
(1.31)\end{array}$ \\
\hline Durable manufacturing & $\begin{array}{r}-0.182 \\
(3.64)\end{array}$ & $\begin{array}{r}-0.361 \\
(4.30)\end{array}$ & $\begin{array}{l}0.679 \\
(6.86)\end{array}$ & $\begin{array}{r}-0.078 \\
(3.06)\end{array}$ & $\begin{array}{r}-0.102 \\
(2.61)\end{array}$ & $\begin{array}{l}0.044 \\
(0.63)\end{array}$ \\
\hline Nondurable manufacturing & $\begin{array}{r}-0.078 \\
(2.35)\end{array}$ & $\begin{array}{l}0.067 \\
(2.39)\end{array}$ & $\begin{array}{l}0.225 \\
(3.57)\end{array}$ & $\begin{array}{r}-0.082 \\
(3.08)\end{array}$ & $\begin{array}{r}-0.010 \\
(0.37)\end{array}$ & $\begin{array}{r}-0.122 \\
(1.69)\end{array}$ \\
\hline $\begin{array}{l}\text { Transportation, communica- } \\
\text { tion, and public utilities }\end{array}$ & $\begin{array}{r}-0.103 \\
(2.68)\end{array}$ & $\begin{array}{l}0.000 \\
(0.00)\end{array}$ & $\begin{array}{l}0.086 \\
(0.44)\end{array}$ & $\begin{array}{r}-0.178 \\
\quad(4.63)\end{array}$ & $\begin{array}{r}-0.016 \\
(0.26)\end{array}$ & $\begin{array}{l}0.211 \\
(3.41)\end{array}$ \\
\hline Wholesale trade & $\begin{array}{r}-0.007 \\
(0.27)\end{array}$ & $\begin{array}{l}0.092 \\
(1.83)\end{array}$ & $\begin{array}{l}0.028 \\
(0.21)\end{array}$ & $\begin{array}{l}0.009 \\
(0.20)\end{array}$ & $\begin{array}{r}-0.068 \\
(2.61)\end{array}$ & $\begin{array}{r}-0.055 \\
(0.55)\end{array}$ \\
\hline Retail trade & $\begin{array}{r}-0.242 \\
(3.90)\end{array}$ & $\begin{array}{l}0.305 \\
(4.26)\end{array}$ & $\begin{array}{r}-0.071 \\
(1.19)\end{array}$ & $\begin{array}{l}0.061 \\
(2.24)\end{array}$ & $\begin{array}{l}0.118 \\
(6.65)\end{array}$ & $\begin{array}{r}-0.171 \\
(3.90)\end{array}$ \\
\hline $\begin{array}{l}\text { Finance, insurance, and } \\
\text { real estate }\end{array}$ & $\begin{array}{l}0.055 \\
(2.41)\end{array}$ & $\begin{array}{l}0.068 \\
(0.91)\end{array}$ & $\begin{array}{r}-0.224 \\
(1.77)\end{array}$ & $\begin{array}{r}-0.033 \\
(0.49)\end{array}$ & $\begin{array}{l}0.049 \\
(0.51)\end{array}$ & $\begin{array}{l}0.086 \\
(1.00)\end{array}$ \\
\hline Business and repair services & $\begin{array}{l}0.052 \\
(1.10)\end{array}$ & $\begin{array}{l}0.334 \\
(4.32)\end{array}$ & $\begin{array}{l}0.140 \\
(1.59)\end{array}$ & $\begin{array}{r}-0.030 \\
(0.75)\end{array}$ & $\begin{array}{r}-0.101 \\
(1.32)\end{array}$ & $\begin{array}{r}-0.396 \\
(3.94)\end{array}$ \\
\hline Education & $\begin{array}{r}-0.157 \\
(3.37)\end{array}$ & $\begin{array}{r}-0.085 \\
(1.70)\end{array}$ & $\begin{array}{l}0.189 \\
(2.28)\end{array}$ & $\begin{array}{r}-0.167 \\
(3.32)\end{array}$ & $\begin{array}{r}-0.181 \\
(3.21)\end{array}$ & $\begin{array}{l}0.401 \\
(6.57)\end{array}$ \\
\hline Miscellaneous services & $\begin{array}{r}-0.086 \\
(4.17)\end{array}$ & $\begin{array}{l}0.088 \\
(2.82)\end{array}$ & $\begin{array}{l}0.274 \\
(2.88)\end{array}$ & $\begin{array}{r}-0.080 \\
(2.06)\end{array}$ & $\begin{array}{r}-0.072 \\
(2.54)\end{array}$ & $\begin{array}{r}-0.125 \\
(1.43)\end{array}$ \\
\hline Public administration & $\begin{array}{r}-0.110 \\
(2.93)\end{array}$ & $\begin{array}{l}0.119 \\
(1.69)\end{array}$ & $\begin{array}{l}0.497 \\
(2.36)\end{array}$ & $\begin{array}{r}-0.101 \\
(2.18)\end{array}$ & $\begin{array}{r}-0.242 \\
(3.23)\end{array}$ & $\begin{array}{r}-0.164 \\
(2.92)\end{array}$ \\
\hline
\end{tabular}

Source: Equation (4), discussed in the text, using unpublished data from U.S. Bureau of the Census, Current Population Surveys, for 1961-72. Other parameters of these equations are available from the author on request.

a. The period of fit is 1961-72. The numbers in parentheses are $t$-statistics.

ployment is highest when the employment gap is largest; put conversely, the employment of mature men in durable goods manufacturing rises proportionately less than total employment of that industry when the employment gap is closed. A negative coefficient, like that of women 25 and over in business and repair services, implies that a high-pressure economy increases the group's share of that industry's employment.

Table 7 combines the industry distribution of the 1970 employment gap shown in Table 3 with the demographic shift estimates implied by the $b_{2}$ coefficients of Table 6 . This is obviously a shotgun marriage: The industry elasticities are based on establishment reports of employment for a sample period from 1948-70; the shift estimates come from household reports for 1961-72. The array of numbers in the table is designed to reveal characteristic patterns rather than to provide point estimates.

The first column of Table 7 takes the job gap estimates by industry from 


\section{Table 7. Demographic-Industrial Composition of the Employment Gap, 1970}

Thousands of persons

\begin{tabular}{|c|c|c|c|c|c|c|c|c|}
\hline \multirow[b]{2}{*}{ Industry } & \multirow[b]{2}{*}{$\begin{array}{l}\text { Total, } \\
\text { males and } \\
\text { females }\end{array}$} & & \multicolumn{3}{|c|}{ Males } & \multicolumn{3}{|c|}{ Females } \\
\hline & & & $16-19$ & $20-24$ & $\begin{array}{l}25 \\
\text { and } \\
\text { over }\end{array}$ & $16-19$ & $20-24$ & $\begin{array}{l}25 \\
\text { and } \\
\text { over }\end{array}$ \\
\hline $\begin{array}{l}\text { Agriculture, forestry, } \\
\text { and fisheries }\end{array}$ & -18 & $\begin{array}{l}a \\
b \\
c\end{array}$ & $\begin{array}{l}-2 \\
-6 \\
-8\end{array}$ & $\begin{array}{r}-1 \\
-15 \\
-16\end{array}$ & $\begin{array}{r}-12 \\
19 \\
7\end{array}$ & $\begin{array}{r}0 \\
-4 \\
-4\end{array}$ & $\begin{array}{r}0 \\
-3 \\
-3\end{array}$ & $\begin{array}{r}-3 \\
9 \\
6\end{array}$ \\
\hline Construction and mining & 82 & c & $\begin{array}{l}4 \\
1 \\
5\end{array}$ & $\begin{array}{r}8 \\
-21 \\
-13\end{array}$ & $\begin{array}{l}66 \\
22 \\
88\end{array}$ & $\begin{array}{l}0 \\
1 \\
1\end{array}$ & $\begin{array}{l}1 \\
0 \\
1\end{array}$ & $\begin{array}{r}3 \\
-3 \\
0\end{array}$ \\
\hline Nondurable manufacturing & 141 & $\begin{array}{l}a \\
b \\
c\end{array}$ & $\begin{array}{r}5 \\
9 \\
14\end{array}$ & $\begin{array}{r}10 \\
-8 \\
2\end{array}$ & $\begin{array}{r}73 \\
-26 \\
47\end{array}$ & $\begin{array}{r}3 \\
10 \\
13\end{array}$ & $\begin{array}{l}7 \\
1 \\
8\end{array}$ & $\begin{array}{l}43 \\
14 \\
57\end{array}$ \\
\hline Durable manufacturing & 459 & c & $\begin{array}{l}12 \\
29 \\
41\end{array}$ & $\begin{array}{l}41 \\
58 \\
99\end{array}$ & $\begin{array}{r}311 \\
-109 \\
202\end{array}$ & $\begin{array}{r}5 \\
12 \\
17\end{array}$ & $\begin{array}{l}16 \\
16 \\
32\end{array}$ & $\begin{array}{r}75 \\
-7 \\
68\end{array}$ \\
\hline $\begin{array}{l}\text { Transportation, communica- } \\
\text { tion, and public utilities }\end{array}$ & 92 & a & $\begin{array}{l}2 \\
7 \\
9\end{array}$ & $\begin{array}{l}7 \\
0 \\
7\end{array}$ & $\begin{array}{r}63 \\
-6 \\
57\end{array}$ & $\begin{array}{r}2 \\
11 \\
13\end{array}$ & $\begin{array}{l}5 \\
1 \\
6\end{array}$ & $\begin{array}{r}13 \\
-14 \\
-1\end{array}$ \\
\hline Wholesale and retail trade & 216 & $\begin{array}{l}a \\
b \\
c\end{array}$ & $\begin{array}{l}19 \\
39 \\
58\end{array}$ & $\begin{array}{r}15 \\
-54 \\
-39\end{array}$ & $\begin{array}{r}92 \\
10 \\
102\end{array}$ & $\begin{array}{r}13 \\
-10 \\
3\end{array}$ & $\begin{array}{r}12 \\
-15 \\
-3\end{array}$ & $\begin{array}{l}65 \\
31 \\
96\end{array}$ \\
\hline $\begin{array}{l}\text { Finance, insurance, and } \\
\text { real estate. }\end{array}$ & 15 & a & $\begin{array}{r}0 \\
-3 \\
-3\end{array}$ & $\begin{array}{r}1 \\
-4 \\
-3\end{array}$ & $\begin{array}{r}7 \\
12 \\
19\end{array}$ & $\begin{array}{l}1 \\
2 \\
3\end{array}$ & $\begin{array}{r}2 \\
-3 \\
-1\end{array}$ & $\begin{array}{r}5 \\
-5 \\
0\end{array}$ \\
\hline Private household services & -28 & $\begin{array}{l}a \\
b \\
c\end{array}$ & $\begin{array}{l}-1 \\
-4 \\
-5\end{array}$ & $\begin{array}{r}0 \\
-2 \\
-2\end{array}$ & $\begin{array}{l}-2 \\
-1 \\
-3\end{array}$ & $\begin{array}{r}-5 \\
2 \\
-3\end{array}$ & $\begin{array}{l}-1 \\
-1 \\
-2\end{array}$ & $\begin{array}{r}-18 \\
7 \\
-11\end{array}$ \\
\hline High-wage services ${ }^{A}$ & 34 & c & $\begin{array}{r}2 \\
-2 \\
0\end{array}$ & $\begin{array}{r}3 \\
-13 \\
-10\end{array}$ & $\begin{array}{r}20 \\
-5 \\
15\end{array}$ & $\begin{array}{l}1 \\
1 \\
2\end{array}$ & $\begin{array}{l}2 \\
4 \\
6\end{array}$ & $\begin{array}{r}7 \\
15 \\
22\end{array}$ \\
\hline $\begin{array}{l}\text { Other services }{ }^{B} \text { and } \\
\text { government }\end{array}$ & 29 & c & $\begin{array}{r}1 \\
31 \\
32\end{array}$ & $\begin{array}{r}1 \\
-10 \\
-9\end{array}$ & $\begin{array}{r}11 \\
-80 \\
-69\end{array}$ & $\begin{array}{r}1 \\
31 \\
32\end{array}$ & $\begin{array}{r}3 \\
41 \\
44\end{array}$ & $\begin{array}{r}13 \\
-12 \\
1\end{array}$ \\
\hline
\end{tabular}

Sources: Total from Table 3, with self-employed allocated among industries; others computed from U.S. Bureau of the Census, Current Population Surveys, unpublished data.

Entry $a=$ total times age-sex employment as a share of industry employment $=$ the scale effect (see discussion in text).

Entry $b=b_{2}$ coefficients (from Table 6) times 1970 industry employment times -0.0143 (negative of 1970 relative employment gap) $=$ the shift effect.

Entry $c=$ the total of entries $a$ and $b=$ the total effect.

Details may not add to totals because of rounding.

A. Business and repair shift effect is used for entry $b$. See Table 2, note $b$, for services included in highwage services.

B. The sum of education, low-wage services, and public administration shift effects is used for entry $b$. See Table 2, note $c$, for definition of other services. 
Table 3 with the number of industries slightly condensed for simplification. The remaining columns allocate the incremental employment among the six demographic groups. Each demographic-industrial cell contains three entries. Entry (a) is the number of jobs in that industry that a given demographic group would have obtained if its share of the extra jobs in closing the 1970 employment gap had been the same as its share of actual employment in the industry in 1970. Thus, adult males, who had a little more than half of the jobs in nondurable goods manufacturing in 1970, would, on that basis, have obtained 73,000 additional jobs of the 141,000 created. Entry (a) is thus the "scale effect," reflecting the impact of a proportional increase in employment across the demographic groups within any industry. Entry (b) is the "shift effect"- the result of any systematic tendency for shares of an industry's employment among groups to change when the employment gap is closed. It is equal to $b_{2}$ times industry employment for 1970 times -0.0143 (the negative of the 1970 relative employment gap). Entry (c) is then the net estimated increase in employment for a particular demographic group in an industry, summing the scale effect and the shift effect.

The following estimated results from closing the gap seem noteworthy:

1. Men over 25 leave the low-paying sectors of other services and government in substantial number, reflecting a sizable shift effect and a negligible scale effect. Their places are taken largely by young people.

2. In both categories of manufacturing and in transportation, adult men gain a large number of jobs, but fewer than the scale effect alone would generate. Other demographic groups are able to enter these high-paying industries in substantial number. In durables, the primary substitutes for mature men are younger men, while in nondurables women get most of the extra jobs.

3. In construction-mining, employers apparently believe there is nothing like a man, and all the incremental jobs are filled by men over 25 .

4. The exodus from agriculture is confined to more mobile young people.

5. Trade is the one low-wage nonfarm sector that holds its share of mature men.

6. All in all, the absolute total of shift effects is substantial-indeed, reaching the same order of magnitude (nearly 1 million) as the scale effects. The shift effects generally can be viewed as movements up the ladder, within demographic groups, from low-wage to higher-wage industries.

The estimated shift effects are distorted by one particular characteristic of the 1961-72 period. For males 20-24, movements into and out of the 
armed forces dominated the shifts among civilian industries, and were strongly correlated with the overall employment gap. From 1965 to 1966, while the overall employment gap turned negative, military employment for males 20-24 increased 287,000, but their civilian employment rose only 16,000. By contrast, from 1970 to 1971, while the gap was rising sharply, their military employment fell 255,000 and their civilian employment rose 330,000 . The elasticity of the civilian employment of this group with respect to aggregate employment is below 0.2 for 1961-72, while that of their total employment (including military) is nearly 1.7 (Perry's estimate is 1.4). Hence, the typical shift effect for that demographic group is unrealistically low (the $b_{2}$ is too high) in relation to what would be expected during a peacetime expansion. The puzzling shift of young men out of construction and trade in a high-pressure economy may be primarily a reflection of the Vietnam war.

The opposite side of that coin is that the shift effect does not eliminate enough jobs for men over 25 . They get roughly one-third more jobs than the Perry estimates would imply, apparently at least partly because of the reduced availability of younger men in the late 1960s. As a crude judgment, I suspect that a more realistic peacetime pattern would be obtained by removing one-fourth of the net gains of mature men shown in the table, and attributing them to the younger men of $20-24 .^{21}$

The evidence presented above confirms that a high-pressure economy generates not only more jobs than does a slack economy, but also a different pattern of employment. It suggests that, in a weak labor market, a poor job is often the best job available, superior at least to the alternative of no job. A high-pressure economy provides people with a chance to climb ladders to better jobs.

The industry shifts are only one dimension of ladder climbing. Increased upward movements within firms and within industries, and greater geo-

21. The entire shift effect was also estimated in the opposite direction-distributing the employment of a given demographic group across industries. For example, employment of male teenagers in retail trade as a fraction of total male teenage employment $\left(N_{i d} / N_{d}\right)$ was related to time and the employment gap. That set of equations and equation (4) above provided alternative estimates of each demographic-industrial cell for each year. Although the results were qualitatively similar, equation (4) gave a better fit, with the grand sum of squared errors over the twelve-year period roughly half as large. The alternative approach would have "solved" the problem of males 20-24 by permitting an allocation of the Perry demographic-gap estimates across industries. But then the industry totals would not have agreed with the industry-gap allocation; in fact, one startling discrepancy emerged-retail trade had virtually no job gap. 
graphical flows from lower-income to higher-income regions, are also likely to be significant. Nor is the process confined to age-sex groups. Richard Freeman's paper in this issue demonstrates that black workers benefit especially from upgrading when labor markets are strong.

I have no way of appraising the total value of cyclical upgrading in terms of real wages, or of longer-run career opportunities. I can nonetheless offer one crude calculation of how much the real wage bonus might be worth. While the elasticity of real employee compensation with respect to real GNP is well below unity as the economy moves up to higher utilization, it appears to be at least 0.85 over a horizon of three years. Thus, associated with an increment of output of 2.8 percent accompanying a 1 point reduction in the unemployment rate, would be an increment in the real wage bill of about 2.4 percent. With weights for wages and hours based on demographic reference groups, the Perry labor input gap (reflecting increased hours and participation as well as reduced unemployment) is "worth" only 1.7 percent of extra real employee compensation. If the difference between 2.4 and 1.7 results entirely from upgrading, the upgrading bonus is nearly as large as the gain in the real wage bill associated with rescuing 1 percent of the labor force from unemployment and putting them to work at the average wage rates and hours of their demographic reference groups. If, in fact, the unemployed typically have lower average earnings when employed than the averages of their demographic reference groups, as R. J. Gordon suggests in this issue, the bonus attributable to upgrading may be even greater.

\section{Cyclical Facts and Labor Market Theory}

Although the cyclical process of upgrading has rarely been discussed in the mainstream of macroeconomic employment theory, it has long been recognized by labor economists. In 1955, Reder stated: "When aggregate labor demand increases sufficiently there will be a tendency for the manual labor force, especially the unskilled, to move toward better jobs and for their places to be filled, if at all, by erstwhile members of the labor reserve. This implies a shift of workers from agriculture to industry, from unskilled to semiskilled jobs, etc." ${ }^{22}$

22. M. W. Reder, "The Theory of Occupational Wage Differentials," American Economic Review, Vol. 45 (December 1955), p. 842. 
The facts of cyclical upgrading could be fitted into the traditional framework of labor market theory if wage rates for the usual workers in the highpaid, cyclically sensitive industries rose especially sharply in prosperity, inducing employers to substitute the kinds of workers normally hired in low-paid pursuits. But, as Reder emphasized, the facts do not support that hypothesis, and indeed point in the opposite direction. He showed that differentials among wage rates of more skilled and less skilled occupations have typically (although not universally) tended to narrow in periods of high employment.

The same phenomenon of narrowing wage differentials in prosperity is evident among industries. As Haddy and Tolles reported: "The average wages paid by different industries become more nearly uniform as an economy of the British or American type moves from slack to full employment." ${ }^{23}$ Most recently, Michael Wachter has demonstrated very impressively the negative relationship between wage differentials among U.S. two-digit manufacturing industries and the national unemployment rate. The coefficient of variation among average hourly earnings is about 5 percent lower at 4 percent unemployment than at 5 percent. ${ }^{24}$

The cyclical facts of upward labor mobility cannot be explained in terms of a market-clearing allocation of labor based on relative wage movements. Market queues are an intrinsic part of the story. The nonprice allocation is, in my judgment, best explained in terms of several themes recently stressed in labor market theory: distinctions between employers who aim to establish long-term attachments with their workers, and those who do not; recognition of the fixed and variable costs involved in hiring and training labor; and the analysis of the search process by which the unemployed or new entrants into the labor force acquire jobs. ${ }^{25}$

23. Pamela Haddy and N. Arnold Tolles, "British and American Changes in Interindustry Wage Structure under Full Employment," Review of Economics and Statistics, Vol. 39 (November 1957), p. 414.

24. Michael L. Wachter, "Cyclical Variation in the Interindustry Wage Structure," American Economic Review, Vol. 60 (March 1970), p. 80.

25. Some of the key contributions in this area are: Robert E. Hall, "Why Is the Unemployment Rate So High at Full Employment?” BPEA (3:1970), pp. 369-402, and Hall, "Turnover in the Labor Force," BPEA (3:1972), pp. 709-56; Peter B. Doeringer and Michael J. Piore, Internal Labor Markets and Manpower Analysis (Heath, 1971); Gary S. Becker, Human Capital: A Theoretical and Empirical Analysis, with Special Reference to Education (Columbia University Press for the National Bureau of Economic Research, 1964); Charles C. Holt, "Job Search, Phillips' Wage Relation, and Union Influence: Theory and Evidence," in Edmund S. Phelps and others, Microeconomic Foundations of 


\section{THE TWO-TIER LABOR MARKET}

Drawing on this literature, I shall sketch a model of labor markets in simple and rather extreme form, using it to explain the various phenomena observed in a higher-pressure economy. ${ }^{26}$ Just to use Occam's razor, ignore the existence of unions ${ }^{27}$ and assume there are two types of employers: Class A firms are interested in promoting a long-run attachment of workers, while class B firms do not pursue that objective. Obviously, these two classes are a simplified way of describing a spectrum of employment strategies ranging from firms that care least, to those that care most, about worker attachment. Indeed, the same firm may pursue a class A strategy with respect to some types of workers and a class B strategy with respect to others.

Promoting attachments is attractive to many types of employers: (a) firms that can provide specific training that enhances productivity over time; (b) firms that have a production process in which an inefficient worker would be particularly costly (for example, by snarling an integrated assembly line or abusing expensive machinery); (c) firms with ready and inexpensive access to funds for investment in human as well as physical capital; (d) large firms that hire a sizable portion of the workers in their labor markets and could therefore find rapid turnover of labor very costly because of an inadequate pool of potential applicants. In order to promote long-run attachments, class $\mathrm{A}$ employers establish a schedule of wage increases at

Employment and Inflation Theory (Norton, 1970); Phelps, "Money Wage Dynamics and Labor Market Equilibrium," in Microeconomic Foundations; Perry, "Unemployment Flows"; Walter Y. Oi, "Labor as a Quasi-Fixed Factor," Journal of Political Economy, Vol. 70 (December 1962), pp. 538-55; James Tobin, "Inflation and Unemployment," American Economic Review, Vol. 62 (March 1972), pp. 1-18.

26. See the appendix for a mathematical development.

27. Several aspects of the analysis and discussion that follow are similar to points made by Michael Wachter in three recent articles. The main difference is that he stresses administered price and wage behavior of big firms and unions, while I focus on the longrun attachments between workers and firms. See Wachter, "Cyclical Variation in the Interindustry Wage Structure"; Wachter, "Phase II, Cost-Push Inflation, and Relative Wages," Fels Discussion Paper 23 (University of Pennsylvania, Fels Center of Government, October 1972; processed); Stephen A. Ross and Michael L. Wachter, "Wage Determination, Inflation, and the Industrial Structure," American Economic Review (forthcoming). In addition, Donald F. Gordon has offered a similar analysis in a paper, "The Theory of the Phillips Curve," presented to a conference at the University of Rochester, Center for Research in Government Policy and Business (April 1973; processed). 
regular intervals, fringe benefits and seniority privileges, and institutionalized provisions for leisure through annual leave and paid vacations.

The wage rates paid by class $\mathrm{A}$ employers to a given grade of workers exceed those paid by class B firms. Class A employers provide such a wage premium in order to maintain a reliable work force with a low quit rate and also to ensure a queue of applicants that management can screen before investing in new workers. The evidence is compelling that a significant portion of wage premiums in high-paying industries is aimed at, and succeeds in, holding down quit rates. ${ }^{28}$ By providing a wage premium, class $\mathrm{A}$ employers are able to select the applicants they want, leaving the remainder either on queue for subsequent class $\mathrm{A}$ jobs or else working at lower wage rates for class B firms. In making their selections, class A employers will be influenced by the likelihood that an applicant will stick to his job over the long run. The statistical evidence that young people and women frequently move out of the labor force will influence choices in favor of mature men.

The wage differential between class A and class B workers will be accompanied by a differential in productivity and a differential in unemployment rates. The class A employer of a new worker must expect high productivity, since the marginal revenue product of that worker must cover both the premium over class B wage rates and some amortization of the fixed costs of hiring and training. Once the worker is hired and trained, those investments make his employer less likely to lay him off when markets weaken, for, if he finds a job elsewhere, the firm's capital investment in him would be lost. Therefore, if that capital value is large and the slack period expected by the firm is short, the worker will be retained even if his current marginal revenue product is zero. This "locked in" effect will be smaller (but not absent) if the wage premium offered by the firm is so large that it can lay off workers "without prejudice" and still get most of them back when they are again needed. Thus because the wage premium holds down the quit rate and the sunk training costs hold down the layoff rate, class A workers have less turnover and fewer spells of unemployment.

On the other hand, class B firms hire workers and lay them off without inhibition, depending merely on whether their near-term contributions to

28. For evidence on the strong negative correlation of wage rates and quit rates among industries, see Lloyd Ulman, "Labor Mobility and the Industrial Wage Structure in the Postwar United States," Quarterly Journal of Economics, Vol. 79 (February 1965), pp. 81-85; Oi, "Labor as a Quasi-Fixed Factor," pp. 552-53; and John H. Pencavel, "Wages, Specific Training, and Labor Turnover in U.S. Manufacturing Industries," International Economic Review, Vol. 13 (February 1972), pp. 53-64. 
marginal revenue product cover their wages. Moreover, the class B workers are likely to have high quit rates because they are tempted to search for a class A job, because they do not have the same opportunities for leisure without quitting that are provided for class A workers, and because they have no lasting stake in their jobs. As a result, class B workers experience higher unemployment rates in any given state of the overall labor market.

In the two-tier labor market, the overall unemployment rate at any sort of equilibrium will thus depend on the proportions of class A and class B workers. Given labor supplies, higher relative demand for labor by class A firms raises the wage premium and lowers the global unemployment rate in any equilibrium. Over the long run, increases in physical capital per worker and in the complexity of technology seem likely to keep pushing personnel strategies toward more class A workers. Rising educational attainment should also promote the class A personnel strategy as workers become more adaptable to specific training. If such forces outweigh any counterforces, the global unemployment rate prevailing in an "equilibrium" of the two-tier labor market would tend to decline over the long run. One obvious counterforce could be a shift in the composition of the labor force toward those demographic groups regarded as less eligible for class $\mathbf{A}$ jobs-such as the Perry shift. (Another counterforce in the real world is the secular decline in the number of self-employed, since they are rarely unemployed.)

In the very short run, firms cannot readily shift between class A and B personnel strategies. But some of the responses to innovation, unionization, and minimum wage increases suggest that, with major incentives, firms can and do alter their technologies and personnel strategies rather promptly. Because the "equilibrium" overall unemployment rate changes over time in response to shifts in technology, education, and demography, the concept of a "natural" unemployment rate is likely to be more misleading than instructive.

Finally, wage rates are likely to be more sensitive to easing and tightening of the labor market in class B than in class A firms. The arrangements designed to promote job attachment in class A put wage decisions into a longer-run context, insulating them from cyclical fluctuations. The division of the return from firm-specific human capital between employers and workers may be the big long-term issue for bargaining in class A firms. Because of the typical queue of applicants at their hiring gates, their wage rates need not rise to permit increased employment. Conversely, in a weak 
labor market, they cannot be cut-perhaps not even readily slowed downbecause established workers expect to get "equitable" annual increases in pay.

\section{THE DYNAMICS OF AN UPSWING}

Suppose that an economy with a two-tier labor market is initially in equilibrium in the sense that wage rates are, on balance, neither accelerating nor decelerating, and that class A and class B employers have no net incentives to alter the wage differential. Now suppose that equilibrium is disturbed by an increase in the aggregate demand for the output of both class A and class B firms. If the marginal revenue product of class A workers becomes sufficiently high to cover hiring and training costs as well as the wage (including the premium over the class B rate), class A firms will expand employment. If class A firms have some slack in their utilization of physical and human capital, they can expand employment and production in the short run with reduced costs and increased productivity. Under such circumstances, they are likely to respond primarily by expanding production rather than by raising prices.

Because of their wage premium, class A firms can get additional workers merely by hanging up the help-wanted sign, and perhaps by improving the information on the availability of jobs (for example, by spending more on help-wanted advertising). Because marginal hiring and training costs may rise with the rate of inflow of new workers, the firm may adjust initially in large measure by increasing the workweek even at the cost of paying overtime premiums. But class A firms will not need to raise wage rates immediately; moreover, general wage increases (outside of the regular schedule) would be costly since they would have to cover existing workers as well as new employees. Among the efficient adjustments confined to new workers are changes in hiring standards, such as accepting younger and less experienced people, or shifting from "statistical" rules that exclude women or people without diplomas to a more intensive personal screening of applicants.

The upswing affects class B firms quite differently. Workers leave readily to take class A jobs, and competition for workers among class B firms is likely to increase wages promptly. The wage increases, in turn, are likely to push up prices in class B industries, such as low-skill services, which have few opportunities to spread overhead costs if they should expand output. 
And rising prices will tend to cut their share of real output, even if demands for their output rise as rapidly as those of class A. In fact, the most cyclically sensitive demands for output appear to be concentrated in class A sectors, thus accentuating the relative shift of resources to class A firms, and reinforcing the increase in aggregate productivity. Thus, paradoxical results emerge: The biggest (and earliest) inflationary movements occur in the wage rates of workers with the highest unemployment rates and with the smallest increase in the demand for their typical services, and in the prices of products experiencing the least expansion of demand.

The number of persons employed in the class B areas may rise or fall, depending on the income and price elasticities of the demand for output and on the shrinkage of the supply of labor to class B resulting from the exodus of labor to class A. In extreme cases, such as farm workers and domestic workers, class B industry employment falls; in most cases, however, industry employment rises although its share of aggregate employment falls.

\section{WORKERS' RESPONSES}

Viewed in terms of the behavior of workers, how does the strengthening of labor demand reduce unemployment rates and increase participation rates? First, the number of spells of unemployment declines because a larger fraction of workers make transitions between jobs without an intervening spell of unemployment, ${ }^{29}$ revealing that on-the-job search has some efficiency. Second, the duration of spells falls because a rational job seeker will spend less time searching for a job. Because a larger fraction of firms will be making offers, the job seeker can obtain a reasonable sample in a shorter time. The optimum strategy will lead the job seeker to collect more offers in a firmer labor market but to spend less time between jobs collecting them. For the same reasons, the job seeker is less likely to settle for a class $\mathrm{B}$ job when he perceives a better chance of getting class A employment fairly promptly.

A variety of forces operate to encourage some nonparticipants to enter the labor market and search for jobs. The concepts developed by R. J. Gordon in this issue illuminate those forces. Better information about job availability reduces the cost of search, while the value of search activity is

29. Perry, "Unemployment Flows." 
raised by the greater probability of getting a reasonable job in a reasonable amount of time. For a woman with children, the setup costs associated with undertaking search activity and making the preparations to accept a job may be very large; the willingness to make that investment quite reasonably depends on the prospective availability of a satisfactory job.

In some early formulations of search theory, the reduced duration of unemployment and increased participation rates of a high-pressure economy emerged as a mystery. To solve that mystery, the deus ex machina of money illusion had to be invoked: People are fooled by higher money wage rates and take jobs too readily on the mistaken view that they offer higher real wages. But those models assumed that firms were always willing to hire new workers at some wage, even in a depression. The mystery dissolves once the market-clearing assumption is relaxed to recognize that class A firms will often not be hiring at all and will not accept an applicant at a substandard wage rate. As Tobin has stressed, explaining the cyclical movement of duration and participation does not require the "inflation illusion story." 30

\section{LONGER-RUN ADJUSTMENTS}

If pressure on the labor market is maintained, the inflation originating in class B firms will ultimately spread to class A wages and prices. As queues of applicants shorten, class A employers may begin competing with one another for workers. Meanwhile, the rising prices of class B output reduce the real wages of workers in class A. At the next scheduled adjustment, wage increases by class A firms are likely to be accelerated.

Some forces thus operate to restore the wage differential between class A and class $\mathrm{B}$, but the evidence suggests that they work very slowly. ${ }^{31}$ The formal model in the appendix reveals the possibility that such a system has a negatively sloped Phillips curve in which lower unemployment can be achieved at the cost of a higher, but ultimately steady, inflation rate.

The steepness and stability of the Phillips curve depend on the speed and intensity with which class A wages chase class $B$ wages and prices. If class A workers have the determination and the market power (in the real world, through unions) to resist any narrowing of their wage premium over class

30. Tobin, "Inflation and Unemployment," pp. 6-7.

31. Wachter, "Cyclical Variation in the Interindustry Wage Structure"; Arnold H. Packer and Seong H. Park, "Distortions in Relative Wages and Shifts in the Phillips Curve," Review of Economics and Statistics, Vol. 55 (February 1973), pp. 16-22. 
$\mathrm{B}$, inflationary pressures will be strong, as each rise in the wage rate of class B workers spurs an attempted catch-up in the next class A round. But if class A employees have such power to veto a narrowing of the premium, the economy could not adapt to a rise in the relative supply of class A workers any more than to increased aggregate demand. The possibility of accelerating inflation arises if, over time, the catch-up intervals become shorter and shorter or the game of catch-up is converted into one of leap frog. Although conceivable, such patterns do not seem realistic, in my judgment. In short, the model of a two-tier labor market seems to reinforce the plausibility of the usual empirical finding that the U.S. economy does not exhibit indefinitely accelerating inflation at moderately low unemployment rates.

Some of the forces operating over time are benevolent, and tend to promote a deceleration of inflation at a given unemployment rate. First, the period of high pressure builds up skills and human capital (as well as physical capital) in the class A sector. Entry and exit from class A jobs are asymmetrical; for reasons discussed above, investment in training tends to lock in employers and employees. Even if they should leave their jobs, the new class A workers will have the benefits of some general training and experience that make them more employable in other class A firms. In this way, at least to some extent, the demand for labor creates its own supply.

Second, some employers providing class B jobs may respond to the narrowed wage differential by gradually shifting their personnel strategies and starting to invest in firm-specific human capital-a decision that is likely to be nonreversible. In response to the tight labor market of the late 1960s, some firms adopted more capital-intensive techniques even though capital costs were rising as rapidly as labor costs. A possible interpretation is that increasing capital intensity economizes on personnel costs by shifting toward the more reliable and longer-attachment type of labor. Such a change in the A-B mix generates a favorable shift in the Phillips curve, with less unemployment due to turnover and diminishing inflation at a given unemployment rate. Such a happy ending seems to require that the wage differential between classes A and B remain narrower than initially, although, so long as some productivity bonus persists, class A workers may be able to earn real wages as high as otherwise.

In many respects, the model of a two-tier labor market accords with the facts of inflationary behavior in the excessively high-pressure labor market of the late sixties. It suggests that the loss in the relative wage position of 
some key unionized industries in 1966-69 may have been more than a mere accident of contract schedules; it explains why areas of labor-intensive services were so inflationary, and why wage rates of low-skill groups like hotel workers rose so strongly. The queues in class A sectors can also account for the mystery that unemployment continued to exceed measured vacancies even in a world of excess demand.

The model also may throw some light on developments in 1970-71, when the economy weakened after a sustained interval of high-pressure operation. The large union settlements during the recession may signify that the "old" class A workers felt cheated and pressed hard for a restoration of their initial wage differentials, even in a very weak labor market. Similarly, after a long period of upgrading, "new" class A workers who were laid off in 1970-71 may have been especially reluctant to return to class B underemployment and hence waited for class A jobs. Such behavior might appear to reflect an increase in "structural" unemployment, and perhaps even suggest to some observers that the nation had developed a work ethic problem.

\section{Some Implications for Policy}

The additional jobs available in a high-pressure economy tend to be wellpaid jobs, productive jobs, and potentially steady jobs. Such benefits should be valued and cherished in a democratic capitalistic society. The sacrifice of upward mobility must be carefully reckoned as one part of the high cost of accepting slack as an insurance policy against inflation.

Moreover, the social aspects of the loss of upward mobility seem likely to be compounded by other implications of the low-pressure strategy. In particular, a low-pressure economy is bound to mean a much more restrictive fiscal policy. If society decided to shift from a 4 percent to a 5 percent unemployment target, it would be aiming at a level of real GNP $\$ 35$ billion a year lower than previously. If that reduction of aggregate demand were to be achieved through fiscal policy, the required additional restraint (in real terms) would be about $\$ 15$ billion per year, in some combination of higher tax rates and curtailed expenditures. ${ }^{32}$ It is a fair judgment of our

32. Since a lower level of activity would in itself provide a major disincentive to investment for a substantial period, it is unlikely that a rise in real interest rates would be desired or tolerated. Suppose monetary policy aimed at the same real interest rate that had 
political process that tax rates would not be increased while before-tax incomes were being squeezed. Instead, the major pressure would be exerted on transfer payments for the disadvantaged, manpower programs, and the like, precisely when the increased human costs of a slack economy were being accepted. Meanwhile, society might salve its conscience by concluding that the fault of the unemployed and the underemployed lay in themselves and not in the economic system.

At the same time, this paper should not be read as a clarion call to damn the torpedoes and go full speed ahead. On the contrary, our best hope of achieving 4 percent unemployment with an acceptable price-wage performance rests on our ability to reduce slack more gradually so as to permit smoother and less disruptive shifts of resources, as well as on our willingness to reinforce fiscal-monetary policies with manpower programs and incomes policies.

With the unemployment rate now 5 percent and falling, a major manpower effort to facilitate upgrading seems most promising. The tides are flowing in the direction of upgrading, and government training and information programs may be able to succeed most when they swim with the tide. Barriers to entry into good jobs may be swept away most easily when market forces are making racial and sexual discrimination costly to employers. Now is the time to ask: What incentives can be provided to employers to shift from class B to class A personnel strategies? What kinds of actions can be undertaken to break down barriers of entry that are maintained by discrimination and monopoly power? What kinds of aids to workers now in class B firms can ease the process of movement to good jobs?

This judgment also implies that, in the present situation, manpower programs to aid disadvantaged workers should incorporate a major effort to instill training and the basis for upgrading, rather than merely create more class B jobs. It is tempting to believe that some groups of workers that experience high unemployment rates even in a firm labor market can be aided by the provision of any kind of employment, with little addition to inflationary pressure. But the cyclical record reveals that some groups suffering high unemployment nonetheless have steep Phillips curves. Unless

previously prevailed with the high-pressure target, while fiscal policy was used to restrict aggregate demand by $\$ 35$ billion. In that case, a simple Keynesian multiplier that abstracts from monetary effects would be appropriate. The figure of $\$ 15$ billion emerges with multipliers between 2 and 2.5 for the relevant fiscal instruments. 
some accurate identification of a true "hard core" is possible, a program providing low-skill, dead-end jobs could be just as inflationary as an equivalent program of raising private demand, and yet jeopardize the upward mobility, the productivity bonus, and the building of skills and job attachments that accompany higher pressure in the labor market. In periods of recession and slack, underemployment may be the only alternative to unemployment, and it is surely a lesser evil. But in periods when the economy can move to prosperity, the creation of more class B jobs may substitute underemployment for class A employment.

The need and rationale for incomes policies become evident in the world of a two-tier labor market. Because nonprice considerations already play an enormous role in allocating jobs, moderate and sensible government intervention that curbs the upward movement of average wage rates need not impair the efficiency of allocation of labor. Incomes policies work to the extent that they influence the attitudes of employers and employees about the size of a reasonable wage increase. With $\$ 35$ billion a year at stake, ideas for major institutional revision-like the Wallich-Weintraub tax proposals-deserve a more serious hearing than they have yet received. As an alternative to such tax "sticks," it might be preferable to use tax and subsidy "carrots." Some attractive programs to help gain labor's cooperation with an incomes policy might be devised for a fraction of the cost of a slack economy; these could include cost-of-living subsidies or tax credits payable to workers if prices exceed the targets of a wage-price program. Along with the retired and the rentier, senior class A workers may be one of the few groups in the society that gain little directly from a higher-pressure economy. Some way should be found for them to share in the large social dividend of higher utilization.

The need for upward mobility in our society goes far beyond anything that a reasonable full employment policy can provide, as the unemployment rates and the underemployment of black teenagers in the late sixties will testify. But many other policies to promote upward mobility are probably best accomplished in the context of a higher-pressure labor market. The greater diffusion of opportunity and of upward mobility in a fullutilization economy is a vital social benefit; and that benefit helps to explain why the pursuit of full employment is an integral part of a liberal's creed. 


\section{APPENDIX}

\section{A Model of the Two-tier Labor Market}

TO MAKE THE ALGEBRA tractable, I assume a very unreal world which has no income from property, no changes in productivity within sectors, and no variation in the labor force. Hence, output can be measured in manhour units, and prices are the same as wage rates. Thus, for two sectors, respectively:

$$
\begin{array}{llll}
\text { Output }=\text { Manhours } & A & B \\
\text { Price } & =\text { Wage rate } & a & b
\end{array}
$$

Nominal GNP is thus,

$$
Y=A a+B b
$$

Aggregate demand is determined by a demand-shift parameter, $m$, such that

$$
Y=m Y_{-1} \text {. }
$$

Private demand, monetary policy, and fiscal policy determine $m$.

Expenditure is divided in fractions, $c$ and $(1-c)$, between the two sectors so that

$$
\begin{gathered}
a A=c m Y_{-1} \\
b B=(1-c) m Y_{-1} .
\end{gathered}
$$

In the long-attachment labor market of $A$, wages are determined by

$$
a=a_{-1} W\left[U_{A_{-1}},\left(\frac{a}{b}\right)_{-1}\right] \text {, }
$$

where $U_{A}=$ unemployed (also measured in manhours) seeking A jobs. Wage rates are rigid downward, so $W \geqslant 1$. Both high unemployment and a high relative (real) wage for the sector hold down the rate of wage increase, so the partial derivative of $W$ with respect to each argument is negative: $W_{1} \leqslant 0, W_{2} \leqslant 0$.

Through (3) and (4), $A$ and $a$ for any period are predetermined by $m$, $Y_{-1}, U_{A_{-1}}$, and $(a / b)_{-1}$. Thus, $A$ manhours are absorbed from the fixed total 
labor force (L); so long as $a>b$ and $A<L$, the sector gets the labor it wants.

The labor force consists of those with jobs and those hunting for jobs in each sector, as reflected by the following identity:

$$
A+U_{A}+B+U_{B}=L \text {. }
$$

The labor market in the B sector "clears" in each period, but it is subject to friction and lack of information, which result in unemployment $\left(U_{B}\right)$. For convenience, assume that unemployment is not affected by the state of the labor market and can be taken as proportional to employment in sector B:

$$
U_{B}=f B, \quad 0<f<1 .
$$

The fraction $f$ is typically much larger than $\left(U_{A} / A\right)$. The decision to be in $U_{A}$ is a decision to keep hunting for a job in sector A rather than settling for a class $B$ job. Such a decision will depend, first, on the chances of getting jobs promptly in sector A, which in turn will be greater when $A$ is greater; for this reason an added unit of $A$ reduces $U_{A}$, ceteris paribus, by $(1-e)$ (where $e$ is a parameter such that $0<e<1$ ) rather than by a full unit. Secondly, it will depend positively on $a / b$, the relative wage:

$$
U_{A}=V\left(\frac{a}{b}\right)-A(1-e), \quad V^{\prime}>0 .
$$

Now equations (5), (6), and (7) generate a supply of manhours (output) for the B sector:

$$
B=\frac{L-V\left(\frac{a}{b}\right)-e A}{1+f} .
$$

In conjunction with ( $\left.3^{\prime}\right)$, the demand curve for $B$ output, (8), determines $B$ and $b$, given the predetermined values of $a$ and $A$.

Suppose $m_{0}=1$, and the economy is in equilibrium at $A_{0}, a_{0}, U_{A_{0}}, B_{0}$, $b_{0}, U_{B_{0}}$.

Now, in period $1, m$ rises $\left(m_{1}>1\right)$. Since $a_{1}$ still equals $a_{0}$, the entire increase in demand in the A sector (from equation 3 ) is reflected in more output and employment: $A_{1}=m_{1} A_{0}$. Now consider the $\mathrm{B}$ sector in period 1; demand (from equation $3^{\prime}$ ) at a given value of $a / b$ rises by a fraction $m_{1}-1$; but the supply function (equation 8) shifts left. Therefore, $b_{1}>b_{0}$, but the sign of $\left(B_{1}-B_{0}\right)$ is indeterminate; clearly, however, $B_{1} / B_{0}<A_{1} / A_{0}$. Meanwhile, $U_{A_{1}}<U_{A_{0}}$ as a result of both the rise in $A$ and the rise in $b$. 
For subsequent periods, let $m=m_{1}>1$. In period $2, W$ is pushed up by both its arguments in equation (4), so $a_{2}>a_{0}$. It is not clear whether $A_{2}$ will rise further above $A_{1}$, fall back, or hold steady.

If in some period $t, A_{t}=A_{t-1}$, then $a_{t}=m_{1} a_{t-1}$. In turn, equations (8) and $\left(3^{\prime}\right)$ will then ensure that $b_{t}=m_{1} b_{t-1}$ and $B_{t}=B_{t-1}$; that is, with $A$ the same as in the previous period, $B$ is likewise constant in equations (8) and $\left(3^{\prime}\right)$, so long as $a / b$ is unchanged, both $a$ and $b$ rising at the rate $\left(m_{1}-1\right)$. Then in $(t+1), W$ is the same as in $t$, so $a_{t+1}=a_{t} m_{1} ; A_{t+1}=A_{t} ; b_{t+1}=$ $b_{t} m_{1}$; and $B_{t+1}=B_{t}$. Quantities are thus in equilibrium, and prices and wages in both sectors rise henceforth at the rate $\left(m_{1}-1\right)$.

I shall not try to show the conditions under which this nonlinear system converges to such an equilibrium of quantities and a steady-state inflation. That depends heavily on the shape of the $W$ function in (4). If the response is very gradual, $A$ will move to its new equilibrium smoothly. If, on the other hand, it is extremely strong and rapid, then the system will overshoot and oscillate divergently. If the system does settle down to an equilibrium set- $A^{*}, B^{*}, U_{A}^{*},(a / b)^{*}$, how will those values compare with the levels of period zero?

In an "equilibrium" situation, with $m>1$, the function $W$ in equation (4) must exceed its initial value of unity. Hence, at least one of the two arguments- $U_{A}^{*}$ and $(a / b)^{*}$-must be below its initial value.

In fact, both must be down, as I shall now demonstrate. From (7) rewrite $W$ in (4) as:

$$
W\left\{V\left(\frac{a}{b}\right)^{*}-A^{*}(1-e) ;\left(\frac{a}{b}\right)^{*}\right\} .
$$

If $a / b$ is not below its value of period zero, then $A^{*}>A_{0}$, so that $U_{A}^{*}<$ $U_{A_{0}}$. But in that event, from (8),

$$
V\left(\frac{a}{b}\right)^{*}=L-(1+f) B^{*}-e A^{*} \geqslant V\left(\frac{a}{b}\right)_{0} .
$$

Hence $B^{*}<B_{0}$ since $A^{*}>A_{0}$; but, by (3) and ( $\left.3^{\prime}\right)$,

$$
\frac{A^{*} a^{*}}{B^{*} b^{*}}=\frac{c}{1-c}=\frac{A_{0} a_{0}}{B_{0} b_{0}} \text {. }
$$

This establishes a contradiction since $A / B$ is up, while $a / b$ is assumed not down.

Similarly, if $U_{A}$ is not below its initial value while $a / b$ is, then (9) reveals 
that $A^{*}<A_{0}$. But then (10) will show $V(a / b)^{*} \leqslant V(a / b)_{0}$, and with $A$ down, $B^{*}>B_{0}$. Then both $A / B$ and $a / b$ would be down, contradicting (11).

Hence, any "equilibrium" (for $m_{1}>1$ ) must entail:

$$
\left(\frac{a}{b}\right)^{*}<\left(\frac{a}{b}\right)_{0}
$$

-a shift in real (relative) wages unfavorable to those initially working in sector A;

$$
U_{A}^{*}<U_{A_{0}}
$$

-a drop in unemployment in the A sector;

$$
\frac{A^{*}}{B^{*}}>\frac{A_{0}}{B_{0}}
$$

-upgrading and a "productivity bonus" (see 11);

$$
A^{*}>A_{0}
$$

-an absolute expansion of output and manhours in sector $\mathrm{A}$; this is true because $(1+f)(B / A)=(L / A)-\left(U_{A} / A\right)-1$, and it must be down while $U_{A}$ is down; and

$$
\frac{a_{t}}{a_{t-1}}=\frac{b_{t}}{b_{t-1}}=m_{1}-1
$$

-steady inflation.

As in the case of the impact effect, the ultimate effect on $B$ and $U_{B}$ is indeterminate in sign (remember the empirical findings on farm workers and service workers). But total unemployment is clearly down; by (6), (7), and (8):

$$
U_{A}+U_{B}=\frac{f}{1+f} L+\frac{1}{1+f} V\left(\frac{a}{b}\right)-\left(1-\frac{e}{1+f}\right) A .
$$

Both the drop in $a / b$ and the rise in $A$ reduce total unemployment.

In short, if this system converges, it has to be a Phillips curve world. Lower unemployment can be bought "permanently" by accepting some ultimately steady rate of inflation. Each $m$ generates a point on the longrun Phillips curve, and the curve has a negative slope.

The possibilities of accelerating or decelerating inflation-for given low unemployment rates - can be analyzed by amending the model.

Acceleration can be interpreted in terms of wage determination in the A sector, as described by equation (4). As one convenient device, let the time 
period of the lag in (4) be a variable influenced by the extent and duration of the shortfall in $a / b$ below some normal ("target," "expected," "equitable") level. The lag might shorten as frustration over the depressed level of $(a / b)$ mounts. For example,

$$
\begin{gathered}
a=a_{-\theta} W\left[U_{A-\theta},\left(\frac{a}{b}\right)_{-\theta}\right] \\
\frac{1}{\theta_{t}}=\int_{t-p}^{t} Y\left[\left(\frac{a}{b}\right)_{n}-\left(\frac{a}{b}\right)_{x}\right] d x,
\end{gathered}
$$

where $\theta$ is the variable lag; $n$ refers to "normal"; $p$ is the relevant length of past calendar time influencing attitudes; and the function $Y$ is positive with $Y^{\prime}>0$. So long as $(a / b)$ is held below its normal level, the wage lag in (18) shortens, thus preventing the Phillips result outlined above.

Similarly, incomes policy can be viewed as an effort to reduce the direct influence of $a / b$ in (4)-ideally, to eliminate it. The direct role of $a / b$ in (4) reflects attitudes and expectations as distinct from the indirect effect of $a / b$ on $W$ via (7), which reflects workers' decisions. Eliminating the direct effect would allow a given rise in $m$ and hence in $W$ to cause a larger drop in $U_{A}$ and (via 7) also in $a / b$, offset by a larger rise in $A$. The Phillips curve would then be more favorable, yielding a lower unemployment rate for a given inflation rate, but "old" A workers would then suffer a larger drop in relative (real) wages.

Finally, deceleration of inflation at a given low unemployment rate could work through either of two mechanisms: first, by demand for A labor gradually creating its own supply; or, second, by an induced "secular" contraction of the B sector.

The first route could run as follows: Among workers in $U_{A}$ in any period, those with some qualifications for or experience in A jobs hold down $W$ more than others. The available stock of experience $(X)$ in $U_{A}$ is an integral related to the difference between the present level of employment in A and its levels over the relevant past (from $t-q$ to the present, $t$ ). Attrition, turnover, friction always result in the presence of some experienced workers in $U_{A}$, but they will be fewer when $A$ has risen rapidly from earlier levels and will expand as $A$ tends to reach a stable higher plateau. Thus, (4) is revised to include a third argument, $X$, in $W\left(W_{x}<0\right)$; where $X$ is:

$$
X=\int_{t-q}^{t} Q\left(A_{h}-A_{t}\right) d h,
$$

and $Q \geqslant 0$ and $Q^{\prime}>0$. 
When $A$ jumps, the "quality" of $U_{A}$ will be low, intensifying inflationary pressure. But as $A$ approaches an equilibrium value (assuming the system is converging), the quality of $U_{A}$ reflected in $X$ keeps improving and may push $A$ perpetually upward above the equilibrium that would have otherwise prevailed, with gradually diminishing unemployment at a given inflation rate.

Second, a maintained low $a / b$ may lead some B sector employers to switch strategy and hire A-type workers. The contraction of the B sector can be viewed as proceeding at a time rate, $z$, which depends on $a / b$, such that

$$
z_{t}=Z\left(\frac{a}{b}\right)
$$

where $z=0$ for all $a / b \geqslant(a / b)_{0} ; z>0$ for all $a / b<(a / b)_{0}$; and $Z^{\prime} \leqslant 0$.

The cumulative shift of output then affects the demand equations (3) and $\left(3^{\prime}\right)$, which must be replaced by

$$
\begin{gathered}
A=\frac{c m Y_{-1}}{a}+\int_{0}^{t} z_{j} B_{j} d j \\
B=\frac{(1-c) m Y_{-1}}{b}-\int_{0}^{t} z_{j} B_{j} d j .
\end{gathered}
$$

By shifting jobs and output away from the sector of high frictional unemployment, this process might lower total unemployment gradually over time at a given inflation rate. 


\section{Comments and \\ Discussion}

William Fellner: When editors Arthur Okun and George Perry asked me to be a discussant of this paper, they knew well that, on the central issue under consideration, I would take a position different from that of author Okun.

Unlike Okun, I believe that those social problems that remain unresolved when our general unemployment rate is down to 5 percent are not conventional macroeconomic problems, and do not call for pumping up the economy beyond that level by expansionary policies. While I consider his analysis very valuable, I regard the link between Okun's analysis and his policy position, or his clear policy inclinations, as tenuous.

This paper describes some important advantages of a 4 percent unemployment economy as compared to one with a 5 percent unemployment rate. The analysis goes far beyond pointing out the advantages mentioned in conventional discussions of employment goals. But the real question here is whether, in the contemporary United States, the attempt to maintain 4 percent unemployment would not result in a 4 percent interlude followed by a period with a rate of unemployment significantly higher than 5 percent -who knows how much higher and who knows for how long? This, I suggest, is the real question. I believe that the paper intends to leave this question open. Furthermore, it seems to me that some essential reasons for being pessimistic in this regard are not considered in the paper.

I interpret Okun as suggesting that, in his high-pressure economy, a significant part of the increased competition for labor might well assume the form of offers, to a larger proportion of the labor force, of "quasi-tenured" 
rather than "nontenured" jobs. To this extent, there might develop no wage-raising effect because the quasi-tenured jobs are preferred by workers at the existing wages of these jobs. The wage-raising, inflationary, effect would therefore develop mainly through competition for those workers who would continue to be hired for nontenured jobs, and who would then have the ability to narrow their wage differentials as compared with those for quasi-tenured types of labor. In such a model, the prospect would be good of avoiding accelerating inflation, and of thus approximately stabilizing the employment rate in a high-pressure economy. The system could then be geared to a steady rate, or possibly even decelerating rate, of price increase at a 4 percent unemployment rate.

I find it difficult to follow this reasoning, however, because I do not understand why, at an approximately stable 4 percent rate of unemployment, individual employers seeking to hire more quasi-tenured workers should not keep competing with increasing intensity for the quasi-tenured workers of other employers. After all, a great many competing firms are likely to share the view that these workers are more promising candidates to fill quasi-tenured jobs than are the workers who typically have filled nontenured jobs.

A favorable differential impact on the wages of nontenured workers, with little inflationary impact on the wages of quasi-tenured labor, might indeed develop if the reduction of the unemployment rate to 4 percent were clearly temporary (in which case the demand for quasi-tenured labor would not increase), and if unions were incapable of securing the same wage increases for quasi-tenured as for nontenured workers. But I see no reason for expecting this outcome on the assumption that the 4 percent unemployment rate becomes approximately stabilized, for in that case more quasitenured workers would be demanded. I would then expect the competition for the quasi-tenured workers of rival employers to become increasingly keen.

At a 4 percent, or for that matter at a $4 \frac{1}{2}$ percent rate of general unemployment arrived at by expansionary policies, some major sectors of the present American labor market would be exceedingly tight, very much more so than was the case at slightly above 4 percent in 1956 or 1957 . To illustrate: Even quite recently, at a general unemployment rate of 5 percent, the specific unemployment rate for married men has been the same as in 1956, and that for adult men merely a shade higher, with allowance for differ- 
ences in estimation procedures between 1956 and the present. Okun has argued elsewhere that such indicators of relative tightness in the recent period, as compared with 1956-57, may perform poorly, because in the meantime the occupational composition of the labor force has changed and the level of education has risen. This is a potentially valid objection, yet it would have been possible to raise it also in 1965, when the facts would not have supported the practical importance of this argument. In 1965, the kind of indicators to which I am calling attention pointed to a slightly tighter labor market than in 1956. In 1965 these indicators performed well, as is witnessed particularly by wage trends for nonunion workers. The labor market was indeed tight in 1965.

Thus, it seems reasonable to expect that, given the present composition of the labor force, a policy aiming for the maintenance of a 4 percent general unemployment rate would greatly tighten certain major sectors of the labor market. At a 4 percent rate, individual employers would be strongly influenced by the risk of being unable to achieve their hiring objectives except by bidding for scarce labor with ever-increasing intensity. As compared with this risk, most employers would associate a relatively small risk to accepting increasingly inflationary wage-cost developments - that is to say, in any specific period, relatively little attention would be paid to the risk that monetary and fiscal policy would fail to vindicate increasingly inflationary cost trends; rather, behavior in the labor market would be dominated by the risk of falling behind in the bidding for workers. Unions would reinforce the resulting tendency toward accelerating inflation, and the probability would be high that after a while policy makers would be forced to end the process by engineering a recession, without being able to predict at all well how high the unemployment rate would rise during the contraction phase and with what speed it would decline in the subsequent recovery.

I will add two brief remarks. Okun expects that in his high-pressure economy productivity would steepen, partly as a consequence of sectoral shifts. Or, rather, he expects at least a once-and-for-all increase in productivity, which would not be offset soon by a worsening of the subsequent uptrend. I suggest that any support for this proposition should be reconciled with the fact that, in the advanced stage of the expansion of the sixties, aggregate productivity trends became very weak.

Okun also suggests that if the unemployment rate could be stabilized at 4 percent, an exceedingly long period would elapse before the shift of workers 
into durable goods industries would be reversed. This guess concerning the long time it takes to eliminate capacity shortages in an economy such as the American would be plausible in a model in which the unemployment rate is first kept at 5 percent for a long period, with no excess capacity, and is subsequently stabilized at 4 percent. But, we are presumably talking about the near future. Not so long ago, in 1969, the unemployment rate was at $3 \frac{1}{2}$ percent; toward the end of 1972 it was about 5 percent with a capacity utilization rate of no more than 80 percent in the manufacturing industries, according to Federal Reserve Board statistics. Unfortunately, these statistics on utilization rates provide no firm basis for answering the question posed here, and hence Okun may well be right. But the problem could stand some elaboration because of the difficulty of estimating numerically the capacity shortages created by alternative employment rates in an economy in which the existing capital stock has developed in the past partly at higher employment rates than we now have.

Okun has again presented a paper of great interest. However, his main thesis would convince me only if he developed stronger propositions about how his 4 percent unemployment rate could be prevented from merely marking a detour to significantly higher unemployment in the future.

Alan Greenspan: My comments complement those of William Fellner. Like him, I was intrigued by Okun's descriptive model of the labor market, and skeptical of the implications Okun himself draws from it. Okun's concepts of class A and class B employment, which he uses as a proxy for a continuum of personnel strategies, describe an important process that has been under way for generations.

Class A employment has been growing as a proportion of the total labor force. Some very interesting questions arise from the paper: Is there a limit to the growth of this proportion? What does this process imply about stabilization policies? First, the main cause of the upward trend in class A employment must be the increase in capital-labor ratios - that is, establishments with very complex equipment must have highly trained personnel, necessitating heavy training and other initial costs. In addition, layoffs involve very considerable costs to these firms, as Okun highlights, much more so than in class B. As a result, the proportion of the total wage bill that is a fixed cost is secularly increasing. In turn, this increase implies that, if the variability of national income is unchanged, the share of property income must be increasingly volatile. 
But, if profits and profit expectations generally become more unstable, then the risk premiums involved in capital investment must rise; or, put another way, the rate of return required to encourage the investment in new facilities must rise. If that profitability is not forthcoming, the ratio of plant and equipment investment to GNP must, under these conditions, be somewhat depressed and consequently the growth in capital-labor ratios must slow down, a development that in turn would impede the growth of class A employment. Thus, a necessary condition for a continuing uptrend in class A employment seems to be increasing cyclical stability of the economy, if significant increases in the residual volatility of profits are to be avoided.

Events in the United States during the last several years, I think, provide us with an example of this process at work in the wrong direction. The growth of class A employment has been retarded by the cyclical instability we have recently experienced. All of this raises the danger Fellner discusses: If we attempt to generate exceptionally high-pressure expansions, we may inadvertently generate the type of instability that makes a 4 percent unemployment rate a temporary wayside to 6 percent. That very instability itself would tend to retard the long-term growth in A-type employment, and dissipate the benefits of the high-pressure economy. Other things being equal, class A employment is undoubtedly superior to class B employment, but it is by no means clear to me that class A employment can be promoted sustainably through high-pressure economic expansions.

Let me put this discussion in the familiar context of the tradeoff between inflation and unemployment. We are concerned about inflation not merely because of some ethical undesirability of upward price movements, but because it implies a certain degree of instability in the system which, in the future, will hamper the attainment of our goals. As we expand class A employment over the long run, we also accept certain types of rigiditiesthat is, increased fixed costs-which put a heavier premium on the need for economic stability. And the major tradeoff becomes the issue of unemployment versus instability, which we must solve down the line.

All of this is relevant to our current experience. We are in a highpressure economy-excessively high-pressure-and we got there inadvertently. The excessive pressure could very well lead to a recession like those of the 1950s; it demonstrates, in my mind, the very serious dangers involved in overheating the economy. 


\section{General Discussion}

Several panel participants questioned the permanence of the upgrading bonus and of the other benefits of high pressure discussed in the paper, and asked how Okun could distinguish between the transitory effects of increasing utilization and the longer-run effects of maintaining a higher level of utilization. R. J. Gordon was pessimistic about the duration of the productivity bonus. In the postwar period, strong gains in productivity have tended to accrue during periods of rapid output growth, but they seemed to erode when the economy settled into a high-pressure state. He underlined Fellner's remark that 1969 was a poor year for productivity and added that 1956 had been as well, and he questioned Okun's generalization that existing studies point to a permanent productivity bonus. Finally, Gordon stated that the shift toward durable goods manufacturing, which is so strong in Okun's findings, could not persist for very long. He suggested that investment models could be used to determine the appropriate timing of this cyclical response. He also reaffirmed the position he took in his own paper in this issue that part of the cyclical rise in average weekly hours was transitory.

William Nordhaus observed that Okun's short-run employment elasticities for all industries correlated very closely with his own previous calculations of short-run output elasticities. But the long-run calculations implied by Okun's study yielded elasticity estimates that differed substantially from Nordhaus'. On those grounds, he was not convinced of the permanence of the upgrading effects and suggested that they be explored in greater detail by alternative regression models. However, he disagreed with R. J. Gordon's a priori rejection of long-run increasing returns to labor, pointing to engineering studies in the industrial sector that corroborated such returns. William Brainard also asked how an altered composition of output could be sustained indefinitely by a one-time step-up in utilization.

Arthur Okun responded to these criticisms and questions in various ways. When economy-wide productivity or average hours are analyzed, Okun maintained, both a rate-of-change and a level effect can be identified. The level effect on the workweek implied quite reasonably that additional overtime and less part-time work would occur in a world that had higher quit and layoff rates, and higher costs of recruitment. As to the permanence of a level effect in productivity, he emphatically reiterated that most, al- 
though not all, previous statistical studies in the area had indicated longrun increasing returns to labor. The poor productivity performance of 1956 and 1969 seemed quite consistent with a favorable level effect offset by an unfavorable change effect, reflecting the unusually slow growth of output in those years. He reminded the group that productivity had remained strong relative to trend through mid-1968, and deteriorated only when the economy's pace slackened.

Okun stressed that he was claiming not that all the upgrading effects he uncovered were permanent, but only that they lasted long enough to be important. He also noted that, while the estimated shift toward durable goods was very large, the larger part of the upgrading bonus in terms of productivity, wages, and fringes reflected the exit of workers from lowwage industries, rather than their entry into durables. In a firm labor market, the supply of workers for domestic service and farm jobs could be lower than otherwise indefinitely, because fewer people would be seeking refuge from unemployment by taking those unattractive jobs. The price of services relative to durables might therefore rise, permanently raising the demand for vacuum cleaners and dishwashers, for example. He asked those who suspected that the benefits were transitory how they could expect a process of renewed downgrading to operate in a high-pressure economy.

Robert Hall wondered whether the gains in labor mobility achieved through expansion were necessarily reversed by a subsequent contraction. He saw some evidence to support the notion that an expansion imparted a lasting upgrading benefit even if the economy eventually had to return to a position of greater slack.

In another comment, Hall said that one could believe all of Okun's empirical results and yet not accept his policy conclusions, which might call for the impossible assignment of sustaining an unemployment rate below the "natural rate." On this, William Fellner expressed his opinion that the natural rate of unemployment was not the critical issue because he too surmises that a tradeoff does exist over a considerable range of the so-called Phillips curve, in the long run as well as the short run. The critical question relates to the point on the abscissa at which there ceases to exist a long-run tradeoff because here the long-run curve becomes vertical.

Charles Holt agreed with the general thrust of Okun's two-tier model of the labor market. He underlined the fact that Okun's conclusions with regard to upgrading do not depend critically on increases in good jobs relative to other jobs. Upgrading occurs when the total number of all jobs 
rises, since, through employment search, workers will naturally gravitate toward the relatively more attractive, high-wage, jobs. In this regard, he welcomed Okun's suggestion that manpower programs be focused on facilitating upgrading during sustained periods of expansion.

Holt also urged further study of the alternative explanations of increased labor productivity at higher utilization levels: (1) the increased generation of human capital through greater opportunities for learning on the job; (2) the shift in the production mix toward industries with higher levels of capital and technology; (3) the shift from regular time toward overtime, which (despite the time-and-a-half premium) is more cost effective, because it is ordered only as needed, and is used for the production-limiting processes; (4) the stimulation of production through work backlogs, deadlines, and the like; and (5) the limitation of the above effects through fatigue and the accumulation of saving. The lag dynamics of each of these effects would undoubtedly differ. Finally, Holt reported that Franco Modigliani and Ezio Tarentelli have found evidence in data from Italy indicating that high labor utilization there increased human capital, shifted workers out of agriculture, and permanently improved the inflation-unemployment tradeoff.

David Fand wondered whether manpower programs and other measures might be geared to achieve the upgrading benefit without risking excessive aggregate demand. Okun replied that it is not merely a coincidence that higher employment tends to be associated with better jobs. He suggested that successful manpower programs and expansionary policies tend to be complementary rather than substitutive.

R. A. Gordon regretted that Okun's statistical analysis of demographic shifts within industries had to rest on data since 1961, which covered one very long and unusual expansion. Moreover, it was a period of significant adverse changes in the age-sex composition of the labor force. The outlook for the future may be more favorable: The relative fraction of teenagers in the labor force should decline rather substantially, and the 25-to-34 age group of both males and females should rise substantially. Such movements may facilitate Okun's objective of operating a high-pressure economy.

R. J. Gordon urged Okun to recognize explicitly that hiring women and teenagers in sector A is not costless. He agreed that firms had discriminated against these groups in the past for various reasons, but doubted that this discrimination would suddenly disappear in a high-pressure economy. Reiterating Fellner's comments, he felt that firms would have a greater 
inducement to compete against each other for quasi-tenured workers than to hire teenagers and women. But if firms choose to hire the latter, they take on added training costs. Okun agreed that the training costs of any expansion of class A employment were significant, but suggested that they would be reflected in wage offers. He also recognized that competition among firms for experienced class A workers could become intense in a tight labor market; nonetheless, the percentage wage increases of hotel and laundry workers had greatly outstripped those of factory workers from 1965 to 1969. 